\title{
The demand for auditor services in wholly family-owned private firms: the moderating role of generation
}

\author{
Maarten Corten \\ Research Foundation Flanders (FWO) \\ Hasselt University, KIZOK Research Centre \\ E-mail: maarten.corten@uhasselt.be \\ Tensie Steijvers \\ Hasselt University, KIZOK Research Centre \\ E-mail: tensie.steijvers@uhasselt.be \\ Nadine Lybaert \\ Hasselt University, KIZOK Research Centre \\ E-mail: nadine.lybaert@uhasselt.be
}

Former audit demand studies generally consider wholly family-owned private firms as a homogeneous group of firms that incur minimal agency costs. Family firm literature, however, argues that these firms might incur significant agency costs as well and we therefore examine audit demand in this particular type of firms. As we examine private family firms from the US, which have no audit requirement, we broaden the concept of audit demand to the demand for auditor services, which encompasses audits, reviews and compilations. Consistent with former audit demand studies, we hypothesise a negative association between management ownership and the demand for auditor services but only for first generation private family firms. We hypothesise that this relation turns positive for subsequent generation private family firms due to entrenching behaviour caused by weakened altruistic feelings between the family shareholders. Our results support this hypothesis but only regarding the demand for reviews and compilations. Therefore, our findings suggest that reviews and compilations seem to be sufficient and more cost-effective in this specific context to mitigate shareholder-manager agency costs compared to more expensive audits. Moreover, results suggest that the level of shareholder-debtholder agency costs do seem to be a driver for the demand for audits.

Keywords: audit demand, voluntary audit, private family firms, agency theory, generation 


\section{Introduction}

Although audit demand research, consisting of both audit quality demand and voluntary audit demand research, is still mainly focusing on listed companies, a few interesting studies examining audit demand in a private firm context have recently been published (Carey et al. 2000, Collis et al. 2004, Niskanen et al. 2010, Collis 2012, Niemi et al. 2012). While these studies recognise a family firm effect on audit demand, they generally consider the presence of non-family members to lead to agency costs, thereby considering wholly family-owned private firms as a homogeneous group of firms that incur a minimal level of agency costs. However, as family firm literature argues that these firms can also incur a significant amount of agency costs, we want to complement the aforementioned studies and audit demand research in general by focusing on the heterogeneity within the group of private family firms. More specifically, by examining wholly family-owned private firms, we eliminate the possible influence of conflicts that arise between family and non-family shareholders, and focus solely on the audit demand effect of agency conflicts between family ownermanager(s) (often referred to as the active owners as they are both owner and manager) versus passive (not part of the management team) family shareholders on the one hand and between family shareholders (active and passive) versus debtholders on the other. Moreover, grounded in family firm research as well (e.g. Miller and Le Breton-Miller 2006, BlancoMazagatos et al. 2007), we argue that the generational stage should be considered as an important moderator within the audit demand functions of these wholly family-owned private firms.

We posit that the generational stage might moderate both the 'management ownership - audit demand' and 'leverage - audit demand' relationship within this context of private family firms. Although a negative association between management ownership and audit demand is generally hypothesised within audit demand literature because of the interest 
alignment effect of management shareholdings (more management ownership leads to a lower level of agency costs), we also take into account the possible influence of an opposing entrenchment effect, in which owner-managers will use their equity positions to divert resources away from the firm (more management ownership leads to a higher level of agency costs) (Morck et al. 1988, Short and Keasey 1999), by considering the influence of the generational stage. More specifically, we expect this entrenchment effect to dominate in subsequent generation private family firms while having a prevailing interest alignment effect in first generation private family firms. Unlike first generation owner-managers whose altruistic feelings toward their family will lead them to take into account the needs of all family members, subsequent generation owner-managers will prioritise the interests of their own immediate families (Blanco-Mazagatos et al. 2007). Due to a diminishing feeling of altruism towards their extended family, they may be more inclined to (mis)use their discretion over the firm's assets. In contrast to first generation private family firms, we therefore hypothesise a positive association between management ownership and the demand for auditor services in subsequent generation private family firms. The decrease in altruistic feelings among the family members involved in subsequent generation private family firms combined with the potential incompetence of family descendant-managers due to adverse selection may also deteriorate the shareholder-debtholder relationship (e.g. Anderson et al. 2003, Blanco-Mazagatos et al. 2007). Therefore, we hypothesise that the positive association generally found between leverage and audit demand is higher for subsequent generation private family firms.

Besides considering the internal heterogeneity of wholly family-owned private firms, we also take into account the external heterogeneity related to auditor services used by US private firms. As US private firms are not required to have their annual accounts audited, they can also signal the true and fair view of their accounting figures by other means than by 
demanding an audit. Reviews and compilations could also be considered as valuable devices to reduce information asymmetries, and therefore we do not only focus on 'audit demand' but broaden our empirical research to the 'demand for auditor services', encompassing compilations, reviews and audits. More specifically, we examine the demand for 'auditor engagement', indicating whether the firm had any form of engagement with an auditor (irrespective of whether this engagement relates to an audit, review or compilation), by employing a multivariate logit analysis. Moreover, we also examine the demand for the level of 'auditor assurance' by an ordered logit regression analysis as a higher level of assurance about the validity of the financial statements is obtained for audits than for reviews. The level of obtained assurance for reviews is, in turn, higher compared with compilations. Finally, we also examine the demand for the three services separately by estimating multinomial logit regressions to get a more detailed view about how management ownership and leverage are related to the demand for these services and how these relationships are moderated by generation.

Using a cross-sectional sample of 482 wholly family-owned and family-managed private firms, gathered by the 2003 US Survey of Small Business Finances, the results of our study indeed reveal that the generally hypothesised negative association between management ownership and the demand for auditor services only applies to first generation private family firms while turning positive for subsequent generation private family firms. However, this relationship was only found when including 'auditor engagement' as dependent variable. No significant relationship between management ownership and 'auditor assurance' was found. The more detailed multinomial logit analysis suggests that the association between management ownership and the demand for auditor services and the moderating effect of generation only holds regarding compilations and reviews but not regarding audits. This may be due to the fact that passive family shareholders in private 
family firms are likely to be able to acquire insider information if necessary and therefore do not require an audit (by which a high level of assurance is obtained about the validity of the financial statements). However, as this insider information can be biased as well, our results suggest that passive family shareholders are likely to demand a compilation or a review when shareholder-manager agency costs are high. Even though a lower level of assurance is obtained by these services (a compilation even provides no explicit assurance but can provide some implicit assurance (Johnson et al. 1983)), they seem to provide the passive family shareholders with a monitoring tool that is sufficiently effective in reducing the existing agency conflicts. Moreover, when shareholder-manager agency costs are high, a review or a compilation may be a more cost-effective way to mitigate agency costs since an audit is substantially more expensive compared to a compilation and a review (AICPA, 2010).

This does not seem to be the case for the agency conflicts between shareholders and debtholders as leverage was only found to be positively associated with auditor assurance and not with auditor engagement. Higher levels of assurance therefore do seem better able to mitigate agency conflicts between shareholders and debtholders. The multinomial results partly confirm this since significantly positive coefficients for leverage are only found for reviews and audits. Generational stage was not found to moderate the leverage-auditor assurance/engagement relationship.

The remainder of this paper proceeds as follows. In the next section, we develop testable hypotheses related to the demand for auditor services within wholly family-owned private firms. In section 3, we describe both the data and our methodology. Our results are presented in section 4 and conclusions are drawn in section 5.

\section{Theory and hypotheses}

\subsection{Audit demand: literature review}

Audit demand is generally explained by agency theory, which considers auditing as one of 
the main devices to mitigate agency costs. Agency costs arise in a relationship in which a person (the principal) engages another person (the agent) to perform services on his/her behalf which involves delegating some decision making authority to the agent (Jensen and Meckling 1976, p. 308). As the agent will generally bear only a part of the wealth effects of his/her decisions, agency theory presumes the agent will not always act in the best interest of the principal ${ }^{1}$. Agency problems can be mitigated through explicit contracting (management compensation contracts based on performance, loan agreements, etc.) or implicit contracting (the threat of dismissal in case of disappointing performance) but contracts are often based on accounting numbers prepared by management (Lennox 2005). By verifying the validity of these accounting numbers, auditing reduces the existing information asymmetries between the principal(s) and the agent(s) of a company and therefore its related agency costs (Becker et al. 1998). In this respect, auditing is considered to mitigate agency costs both within the shareholder-manager relationship (first agency cost hypothesis) and the shareholderdebtholder relationship (second agency cost hypothesis) (Jensen and Meckling 1976).

The percentage of shares that is owned by managers (further referred to as management ownership) is generally included in the audit demand model to proxy for the shareholder-manager agency costs as agency theory expects the agency costs to decrease when managers' ownership increases. More specifically, it is assumed that the more shares

${ }^{1}$ In the shareholder-manager agency relationship, agency costs will be generated when the manager does not own $100 \%$ of the company shares '...since he will then bear only a fraction of the costs of any non-pecuniary benefits he takes out in maximizing his own utility' (Jensen and Meckling 1976, p. 312). In the shareholder-debtholder agency relationship, the owner-manager of highly leveraged firms '... will have a strong incentive to engage in activities (investments) which promise very high payoffs if successful even if they have a very low probability of success. If they turn out well, he captures most of the gains, if they turn out badly, the creditors bear most of the costs' (Jensen and Meckling 1976, p. 334). 
managers have, the less they will be inclined towards consuming perquisites to maximise their own utility as the fraction of the costs the managers have to bear for consuming these perquisites is positively related with the percentage of ownership (Jensen and Meckling 1976). Management ownership is thus considered to align the interests between shareholders and managers, and most audit demand studies therefore hypothesised a negative association between management ownership and audit demand. Evidence for this hypothesis was also found by some studies (e.g. DeFond 1992, Firth and Smith 1992) although there are also several studies that did not find significant results with respect to the management ownership - audit demand relationship (e.g. Francis and Wilson 1988, Reed et al. 2000, Piot 2001) ${ }^{2}$.

In order to test the second agency cost hypothesis, leverage (defined as total debt to total assets) is generally added to the audit demand model. Managers are expected to deem the interests of shareholders as more important than the interests of debtholders and the latter may therefore be concerned about possible wealth transfers to shareholders (Jensen and Meckling 1976, Francis and Wilson 1988). Debt agreements therefore commonly include restrictive covenants, which are mostly based on accounting numbers (DeFond 1992). By verifying these accounting numbers, auditors may be considered as able to reduce the agency conflicts between shareholders and debtholders. As the amount of potential wealth transfers is positively related to the amount of debt, audit demand ${ }^{3}$ is expected to be positively related

\footnotetext{
${ }^{2}$ Most of these studies examined firms that were required to have their annual accounts audited. The dependent variable in these studies therefore relates to the choice of a high versus low quality auditor (mostly proxied by a Big $\mathrm{N}$ dummy) instead of an audit versus no audit.

${ }^{3}$ This demand might originate from two reasons. Debtholders might reject a loan application when the financial statements are not verified by an (high quality) auditor, but may also increase the interest rates or collateral requirements. Related to this aspect, several studies (e.g. Pittman and Fortin 2004, Kim et al. 2011) indeed found the cost of debt to be lower for (BigN) audited firms compared to non (BigN) audited firms.
} 
with leverage, which is empirically supported by several studies (e.g. Chow 1982, Francis and Wilson 1988, DeFond 1992, Firth and Smith 1992, Reed et al. 2000, Piot 2001).

Although audit demand seems to be an extensively studied topic, most studies examined the demand for auditing in a context of listed companies while studies focusing on private firms remain scarce. It is, however, argued that the monitoring value of auditing might be at least as important or even more important for private firms as it is for public firms since private firms are less vulnerable to takeovers and are less monitored by analysts, stock markets, etc. (Lennox 2005). Studies such as Collis et al. (2004), Lennox (2005), Niskanen et al. (2011) and Hope et al. (2012) find that there is indeed also a demand for external auditing within private firms when shareholder-manager agency costs are expected to be high. Support for the second agency cost hypothesis is also found within this private firm setting (e.g. Blackwell et al. 1998, Broye and Weill 2008, Kim et al. 2011, Minnis 2011).

If the literature on audit demand in private firms is scarce, it is virtually non-existent for private family firms. This might be due to the fact that agency theory expects the shareholder-manager agency costs to be minimal within private family firms because, besides the concentrated ownership in which the owner and manager are often the same person (leading to high levels of management ownership), '...family members have many dimensions of exchange with one another over a long horizon and therefore have advantages in monitoring and disciplining related decision agents' (Fama and Jensen 1983, p. 306). Although some empirical support for this view is found (Daily and Dollinger 1992, Ang et al. 2000, Chrisman et al. 2004), other studies (e.g. Gomez-Mejia et al. 2001, Schulze et al. 2001, Burkart et al. 2003, Schulze et al. 2003b, Chrisman et al. 2007) contest this view and argue that the 'many dimensions of exchange' in a family firm might lead to even higher agency costs than in non-family firms. 
In contrast to agency theory, which assumes that owners and managers behave in an economically rational way, family firm literature argues that ' .... a relational contract between a firm owned by a family and an agent (a family member) involves a common bond and a set of mutual expectations that are more likely to be based on emotions and sentiments than a non[-]family relational contract. Therefore, family bonds engender agency contracts that are prone to depart from economic rationality' (Gomez-Mejia et al. 2001, p. 82). Because of these non-economically motivated preferences (such as family status), severe conflicts of interest may still arise in family firms (Schulze et al. 2001). Such conflicts may lead to, among other things, poor investment decisions (e.g. owner-managers may veto investments if they could threaten the status quo) (Schulze et al. 2001), recruiting unqualified personnel (e.g. owner-managers might want their son or daughter to work for the firm, even if they lack the necessary competences) (Lubatkin et al. 2005) and free riding (e.g. non-family managers might resent the fact that most career opportunities are based on family status instead of demonstrated performance and might therefore shirk) (Gomez-Mejia et al. 2001). In order to mitigate the related agency costs, an auditor might be appointed in order to be better able to monitor the owner-managers and their effective performance reflected in the firm's accounting figures.

The results of Carey et al. (2000) and Niskanen et al. (2010) support the hypothesis that private family firms also demand auditing in order to mitigate agency costs. However, these studies generally focus on the agency conflicts between family and non-family members, thus assuming that the interests of family members are more aligned. Collis et al. (2004), Niemi et al. (2012) and Collis (2012) analogously hypothesise that wholly familyowned private firms incur a minimal level of agency costs and therefore demand less monitoring. In the next paragraphs, however, we will focus on the agency conflicts that might arise within these wholly family-owned private firms, namely between the active family 
shareholders (the agents) and the passive family shareholders (the principals). More specifically, we will elaborate on how these agency costs differ over generations, arguing that generational stage is an important moderator with respect to the agency cost hypotheses related to audit demand.

\subsection{The moderating role of generation}

\subsubsection{Shareholder-manager agency relationship}

As explained in the previous section, the hypothesised negative association between management ownership and audit demand is founded on the assumption that agency costs decrease when managers' ownership increases due to the interest alignment effect ${ }^{4}$ of management shareholdings, as described by Jensen and Meckling (1976). Within finance literature, however, several studies (e.g. Morck et al. 1988, McConnell and Servaes 1990, Short and Keasey 1999, Cui and Mak 2002) found evidence of an offsetting entrenchment effect within specific regions of management ownership in which there is a positive association between management ownership and the level of agency costs. As larger

${ }^{4}$ In line with Niskanen et al. (2010), we use the term 'interest alignment effect' although other terms exist in the literature as well. Morck et al. (1988), for example, use the term 'convergence-ofinterest' effect and Fan and Wong (2005) refer to the 'incentive alignment' effect to describe the effect that agency costs decrease when management ownership increases. Moreover, several studies (e.g. Lennox 2005) prefer the term 'divergence-of-interests' effect. Although this term seems to contradict the others, it actually refers to the same effect but focuses on a decrease in management ownership (leading to higher agency costs). The term 'divergence-of-interests' effect is actually the most closely related to the description of Jensen and Meckling (1976, p. 313 ) as they describe it as follows: '...[a]s the owner-manager's fraction of the equity falls, his fractional claim on the outcomes falls and this will tend to encourage him to appropriate larger amounts of the corporate resources in the form of perquisites'. In order to make the comparison with the entrenchment effect more clear (which generally focuses on an increase in management ownership), however, we prefer the term 'interest alignment effect'. 
shareholdings give managers more discretion in using the firm's assets for their own purpose, they might be inclined to divert resources away from the firm if the value of this opportunistic behaviour (e.g. perquisites consumption, shirking, etc.) outweighs the loss they suffer from a reduced firm value (Morck et al. 1988, Short and Keasey 1999).

Lennox (2005) and Niskanen et al. (2011) confirm the existence of both an interest alignment effect and an entrenchment effect in a private firm context. Within the context of private family firms, we also expect that both an interest alignment effect, in which management ownership is negatively associated with audit demand, and an entrenchment effect, in which management ownership is positively associated with audit demand, can be at play. In the next paragraphs, however, we argue that the prevailing effect depends on the generational stage the family firm is in. Based on family firm literature, we expect the interest alignment effect to prevail in first generation private family firms, which we define as firms that are still (mainly) owned by the founder(s) of the firm. Additionally, we expect the entrenchment effect to prevail in subsequent generation private family firms, which we define as firms that are (mainly) owned by the descendant(s) of the founder(s). More specifically, we argue that the extent of (parental) altruism in first and subsequent generation family firms has a pivotal role in altering the effect that management ownership has on audit demand.

The economic literature defines altruism as a utility function that positively links the welfare of an individual to the welfare of others (Becker 1981, Stark 1995, Lunati 1997). Parents are concerned about the welfare of their children because they love them but also because they feel compelled to do so. Otherwise, they would harm their own welfare (Becker 1981, Van den Berghe and Carchon 2003).

Altruism will therefore compel first generation owner-managers to take into account the needs of all family members (i.e. themselves and their children) when making decisions. This helps to align incentives among the family members and can reduce information 
asymmetries and resulting agency costs (Van den Berghe and Carchon 2003, Karra et al. 2006). Although higher management ownership would make these first generation ownermanagers more able to expropriate minority family shareholders (i.e. their children), they are not expected to do so as this would harm their own welfare ${ }^{5}$. We therefore expect the entrenchment effect to be minimal in first generation wholly family-owned private firms, leaving the interest alignment effect to prevail and thus having a negative association between management ownership and audit demand.

For subsequent generation private family firms, we hypothesise the opposite. As the interests of descendants will be centred on their own immediate families (their own children) (Blanco-Mazagatos et al. 2007), these descendants will have stronger altruistic feelings towards their own children than towards their extended family. This view is supported by research which shows that '...parents are generally found to be far more generous to their children than children are to either their parents or to each other' (Chakrabarti et al. 1993, Stark and Falk 1998, in Lubatkin et al. 2005, p. 320). Therefore, alignment of interests among shareholders becomes much more difficult to obtain. The potential result is a mix of competing values and interests among owner-managers and other (passive) family shareholders, each getting a different perception of what is best for the firm, which will increase the risk of family conflict (Miller and Le Breton-Miller, 2006).

${ }^{5}$ On the contrary, parents may have a biased perception of the capabilities of their children active in the firm which hampers their ability to discipline them. These children may free ride and shirk, spoiling the firm's resources and thus destroy firm value (Schulze et al. 2001, Schulze et al. 2003b). Although this is often called the dark side of altruism (Lubatkin et al. 2005, Schulze et al. 2003a), it does not necessarily create agency problems in a wholly family-owned private firm if this behaviour does not contravene the goals of the shareholder(s), i.e. the founder(s) (parent(s)) and their children (Chrisman et al. 2004). 
In contrast to first generation private family firms, we expect that an increase in management ownership in subsequent generation private family firms will generate higher shareholder-manager agency costs. Active family owner-managers possessing a higher number of shares might misuse their discretion to achieve personal goals (i.e. goals that increase the welfare of their own immediate families) at the expense of the other (passive) minority family-shareholders (i.e. their brothers, sisters, cousins, etc. or their parents if they still own a minority of the shares) (Miller and Le Breton-Miller 2006). The pursuit of these goals can lead to excessive consumption of perks, exorbitant salaries, investment in low return showcase projects to advance their own career perspectives, shirking, etc. (GomezMejia et al. 2001, Schulze et al. 2001, Schulze et al. 2003b, Poza et al. 2004, BlancoMazagatos et al. 2007). Due to a diminishing feeling of altruism towards their extended family, there is a higher chance that the owner-managers will use the discretion the large ownership share provides them with, in using the firm's assets to achieve their own (i.e. immediate family) goals, hence generating higher agency costs (Miller and Le Breton-Miller 2006, Blanco-Mazagatos et al. 2007).

Overall, instead of the generally hypothesised interest alignment effect, we thus expect the entrenchment effect to prevail within subsequent generation private family firms, which leads us to hypothesise a positive association between management ownership and audit demand in subsequent generation private family firms.

Audit demand, however, should be defined more broadly in the US private (family) firm context as US private (family) firms have no audit requirement and can therefore choose among other auditor services than only an audit. In contrast to the European context, in which an audit firm is mostly hired for having the annual accounts audited, US private companies can choose among three related services (a compilation, a review and an audit) when hiring 
an audit firm ${ }^{6}$ (Blackwell et al. 1998). Which type of auditor service the firm chooses should be based on the firm's needs and the requirements of creditors and investors (AICPA 2010). As compilations, reviews and audits could all be considered as means to reduce information asymmetries, and therefore its related agency costs, we will not only examine audit demand. More specifically, we will examine the demand for auditor engagement, indicating whether the firm had any form of engagement with an audit firm, irrespective of whether this engagement relates to an audit, review or compilation. Following the above arguments, we therefore hypothesise:

H1a: Generational stage will moderate the relationship between management ownership and auditor engagement in such a way that management ownership will have a negative effect on auditor engagement in first generation private family firms while having a positive effect in subsequent generation private family firms.

\subsubsection{Shareholder-debtholder agency relationship}

We argue that the generational stage may also have a moderating effect within the 'leverage audit demand' relationship. As owner-managers of family firms are generally considered to have a long-term perspective because of their often undiversified portfolios and their wish to pass the firm to their children (James 1999, Anderson et al. 2003), they will be less inclined to transfer wealth from debtholders to shareholders and the related agency costs between both

${ }^{6}$ We use the term 'audit firm' or 'auditor' to indicate that these firms provide audit-related services (such as a compilation, review and audit). In the US, however, these firms are generally referred to as CPAs (Certified Public Accountant). Although this name might indicate that the primary services of CPAs relate to accounting and/or bookkeeping services, this is not the case. The provision of assurance services (audits, reviews and compilations) is generally considered as their core business and therefore we prefer the terms 'audit firm' and 'auditor' in order to prevent confusion that might arise when using the term ' $\mathrm{CPA}$ '. 
parties will therefore be relatively low. Moreover, families face reputation concerns arising from the long-term presence in the firm. The owner-manager is aware that one exploitive action on the part of the family can severely damage the family's and firm's reputation (Anderson et al. 2003). Given the low management turnover rate in family firms, ownermanagers keep their positions for a long time. Therefore, banks and other debtholders will often '...develop personal and well-informed relationships...' with these family executives (Anderson et al. 2003, p. 267), which significantly reduces information asymmetries and therefore the related agency costs. However, the strength of these relationships may weaken as generations progress. The initial strong bond between the founder of the firm and a debtholder may fade when descendants take over the firm as they generally do not know the debtholder as well as the founder did. Moreover, the managers' long-term perspective may be weaker or even completely absent in subsequent generation private family firms due to the aforementioned consequences of a greater concern about their own nuclear households since it raises the problem of opportunistic behaviour, such as enjoying excessive salaries and shirking (Blanco-Mazagatos et al. 2007).

Debtholders may further consider family managers of subsequent generation private family firms to be less competent at running the firm since family managers are often selected, irrespective of merit, out of a restricted pool of talent due to parental altruism (Schulze et al. 2001, Schulze et al. 2003b, Lubatkin et al. 2005, Villalonga and Amit 2006, Blanco-Mazagatos et al. 2007). As empirically confirmed by Anderson et al. (2003), this implies that descendant managers might lack the unique, value-adding skills that founders do have, which results in a higher agency cost of debt. These arguments are also consistent with the results of Villalonga and Amit (2006) and Morck et al. (1988), suggesting that founder led (first generation) companies outperform those led by descendants (subsequent generations). 
Following the above mentioned arguments, we hypothesise that subsequent generation private family firms face higher agency costs of debt compared to first generation private family firms. This might lead debtholders to require more monitoring by auditors in subsequent generation private family firms. More specifically, we posit:

H2a: Generational stage will moderate the relationship between leverage and auditor engagement in such a way that leverage will have a stronger positive effect on auditor engagement in subsequent generation private family firms compared to first generation private family firms.

\subsubsection{Auditor engagement versus auditor assurance}

Compilations, reviews and audits differ in the level of assurance that auditors obtain about the validity of the financial statements. The level of obtained assurance is the highest for audits as the objective of an audit is '[t]o obtain a high level of assurance about whether the financial statements as a whole are free of material misstatement thereby enabling the auditor to express an opinion on whether the financial statements are presented fairly, in all material respects' (AICPA 2010, p. 2). This implies that the auditor obtains an understanding of the entity’s internal control and assesses fraud risk, performs inquiry and analytical procedures and performs verification and substantiation procedures (AICPA 2010). For compilation engagements, the auditor does not obtain any assurance as such engagements only imply that the auditor '...assembles the firm's financial information and puts it into a format consistent with GAAP...' (Blackwell et al. 1998, p. 58). The objective of a review is '[t]o obtain limited assurance that there are no material modifications that should be made to the financial statements' and the level of obtained assurance therefore lies in-between those of audits and compilations (AICPA 2010, p. 2). This implies that the audit firm remains necessary to perform inquiry and analytical procedures but should not obtain an understanding of the 
entity's internal control, assess fraud risk or perform verification and substantiation procedures (AICPA 2010).

As a higher level of assurance corresponds to a lower risk of a material misstatement in the annual accounts, we might expect that higher levels of assurance are better able to reduce information asymmetries and therefore the related agency costs. To take this possible effect into account, we will not only examine the demand for auditor engagement, as formulated in $\mathrm{H} 1 \mathrm{a}$ and $\mathrm{H} 2 \mathrm{a}$, but we will also examine the demand for auditor assurance:

H1b: Generational stage will moderate the relationship between management ownership and auditor assurance in such a way that management ownership will have a negative effect on auditor assurance in first generation private family firms while having a positive effect in subsequent generation private family firms.

$\mathrm{H} 2 \mathrm{~b}:$ Generational stage will moderate the relationship between leverage and auditor assurance in such a way that leverage will have a stronger positive effect on auditor assurance in subsequent generation private family firms compared to first generation private family firms.

\section{Data and methodology}

\subsection{Data}

In order to examine the demand for auditor services in US private family firms, we use data from the 2003 Survey of Small Business Finances (SSBF) conducted by the Board of Governors of the Federal Reserve. This database contains information about 4,240 firms, representing 6.3 million small businesses in the United States that were all for-profit, nonfinancial, non-farm and non-subsidiary business enterprises that had fewer than 500 employees and were in operation as of year-end 2003. 
As the dataset contains specific information about ownership characteristics, we were able to exclude all firms that were not wholly (100\%) owned by members of the same family (where family refers to spouses, parents/guardians, brothers, sisters or close relatives), which led to a sample of 677 wholly family-owned private firms. Within this sample, we also removed those firms that were not family managed (31 observations) to eliminate the possible influence of agency conflicts between non-family managers-agents and family shareholders-principals in order to be able to focus on the agency conflicts arising between active family owner-managers and passive family shareholders. Moreover, we excluded 15 outliers $^{7}$ and 149 cases $^{8}$ with missing values, leading to a final sample of 482 firms. In order to alleviate potential outlier problems further, all continuous variables were winsorised at the $1^{\text {st }}$ and $99^{\text {th }}$ percentiles.

\subsection{Model}

In order to test hypothesis $1 \mathrm{a}$ and $2 \mathrm{a}$, we employ a multivariate $\operatorname{logit}^{9}$ regression analysis where the dependent variable, auditor ENGAGEMENT, is a dummy variable coded 1 if the firm's financial statements are audited, reviewed or compiled and 0 otherwise. In order to test hypothesis $1 b$ and $2 b$, we use an ordered logit analysis where the dependent variable, auditor

\footnotetext{
${ }^{7}$ Firms that filed for bankruptcy ( 5 cases), firms that had a negative value of total assets ( 5 cases) and firms with a negative quick ratio ( 5 cases) were considered as outliers and were therefore deleted.

${ }^{8}$ Of these 149 cases, 143 cases were deleted due to a missing value for the variable QUICK. More specifically, as this variable is a ratio (see section 3.2 for more information), these missing values were generated because of a value of 0 in the denominator. As QUICK is considered an important control variable in audit studies, we also included this variable in our study. However, we also ran our models without this variable in the robustness paragraph (see section 4.3) in order to be sure that the removal of these cases did not distort our results.

${ }^{9}$ We prefer logit to probit as both methods are equally efficient but logit does not require normality of parameter distribution (Piot 2001).
} 
ASSURANCE, is an ordinal variable coded 1 if the firm has financial statements that are compiled (but not reviewed and/or audited), coded 2 if the firm's financial statements are reviewed (but not audited), coded 3 if the firm's financial statements are audited and 0 otherwise. This approach corresponds to that of Allee and Yohn (2009) while examining the financial reporting practices of small privately held businesses. Although both dependent variables are hardly used in audit literature focusing on private (family) firms, we believe the inclusion of those variables is necessary to adjust the audit demand model to the context of the US. As audits are not required for private firms in the US, reviews and compilations could be valuable substitutes and should therefore be taken into account as well.

The model we use to test hypothesis 1a and $2 \mathrm{a}$ is specified as follows:

$$
\operatorname{Prob}(\text { ENGAGEMENT })=\frac{1}{1+\mathrm{e}^{-\mathrm{Z}}}
$$

where $\mathrm{Z}=\beta_{0}+\beta_{1}$ MAN_OWN $+\beta_{2}$ GENERATION $+\beta_{3}$ MAN_OWN*GENERATION + $\beta_{4}$ LEVERAGE $+\beta_{5}$ LEVERAGE*GENERATION $+\beta_{6}$ ROA $+\beta_{7}$ QUICK + $\beta_{8}$ DISTRESS $+\beta_{9}$ SIZE $+\beta_{10}$ LIMITED $+\beta_{11, \ldots, 17}$ INDUSTRY $+\varepsilon$

In order to test hypothesis $1 b$ and $2 b$, we include the same independent variables within our ordered logistic regression model and examine their influence on the likelihood of demanding higher levels of ASSURANCE.

Since ordered logistic regression assumes the coefficients not to be dependent on the outcome category (Hosmer and Lemeshow 2000), which is a strong assumption, we also estimate multinomial logistic regressions in which auditor ASSURANCE remains the dependent variable and in which we also include the same independent and control variables. This analysis will give a more detailed view about how generation may affect the relationship both between management ownership and each specific auditor service and between leverage and each specific auditor service. More specifically, it investigates the effect of our 
independent variables on the probability of (1) demanding a compilation versus no auditor service at all, (2) demanding a review versus no auditor service at all and (3) demanding an audit versus no auditor service at all.

MAN_OWN represents the sum of ownership percentages of the top three owners ${ }^{10}$ of the firm who also manage it. Management ownership is frequently used within audit demand models as a proxy for the agency conflicts between owners and managers in order to test the first agency cost hypothesis (e.g. Francis and Wilson 1988, DeFond 1992, Reed et al. 2000, Lennox 2005). Due to our sample of wholly family-owned private firms, all ownermanagers are also family members in this study.

LEVERAGE, defined as total debt to total assets, is included to test the second agency cost hypothesis, which is in accordance with several other studies as well (Francis and Wilson 1988, Reed et al. 2000, Piot 2001, Hay and Davis 2004, Francis et al. 2009, Niskanen et al. 2010, 2011).

GENERATION is a dummy variable coded 1 if the family firm is a subsequent generation family firm and coded 0 if the firm is a first generation family firm. Based on the survey questions, a firm is considered a first generation family firm if the current owners established or purchased ${ }^{11}$ it while it is considered a subsequent generation family firm if the current owners inherited it or acquired it as a gift.

${ }^{10}$ If a firm has less than three owners, MAN_OWN refers to the ownership percentage of the one or two owner-manager(s). We were only able to calculate MAN_OWN based on the ownership percentages of the top three owners because of a limitation of the dataset. In the robustness section (4.3), we therefore also ran our regressions with other proxies for the shareholdermanager agency costs.

${ }^{11}$ In the robustness section, we also ran our regressions without the firms that were 'purchased' as these firms might also include subsequent generation firms that children bought from their parents. 
The interaction variables MAN_OWN*GENERATION and LEVERAGE*GENERATION are included to test our four hypotheses concerning the moderating role of generation within the auditor services demand functions of wholly familyowned private firms.

ROA, QUICK, DISTRESS and SIZE are included as control variables. We included ROA, defined as income after expenses and taxes to total assets, to control for the possible effect of profitability (Niskanen et al. 2010). Both QUICK, which is defined as current assets minus inventory to current liabilities, and DISTRESS, which is a dummy variable coded 1 if the total amount of the firm's equity is negative and 0 otherwise, are indicators for the firmspecific risk of bankruptcy (Niskanen et al. 2010). They are included as risk may engender information asymmetries and therefore the demand for auditor services in itself. SIZE, defined as the natural logarithm of total assets, is included to control for the complexity of firms as more complex firms may demand more monitoring to compensate for the loss of control (Abdel-Khalik 1993).

Finally, LIMITED, which is a dummy variable coded 1 if the firm is organised with limited liability for the owners and 0 otherwise (Allee and Yohn 2009) and INDUSTRY (8 dummy variables referring to the industry each firm is operating in, based on the two-digit SIC codes) are included to control for possible firm type and industry effects. An overview of all included variables can also be found in table 1.

Insert table 1 about here

\section{Results}

\subsection{Descriptive statistics and correlations}

Of all our 482 sample firms, 319 (66\%) were engaged with an auditor. Of these 319 firms, 74 firms had their annual accounts compiled (but neither reviewed, nor audited), 101 firms 
engaged an audit firm to review their financial statements and 144 firms actually demanded an audit. This distribution leads to a mean value of 1.47 for the variable ASSURANCE.

Table 2 presents the descriptive statistics of our sample. In panel A, we report the minima, maxima, medians, means and standard deviations of the continuous variables. Moreover, this panel presents the mean of the variable MAN_OWN and LEVERAGE for both first and subsequent generation private family firms and also presents the $p$-values of the mean-comparison t-tests. We also compare the means of each continuous variable between firms that engaged an auditor for some type of auditor service (ENGAGEMENT=1) and firms that did not (ENGAGEMENT=0). In line with the first agency cost hypothesis, firms that engaged an auditor have a significantly lower average management ownership percentage compared to firms that did not engage an auditor. The level of leverage is not found to be significantly different between firms that engage an auditor and those that do not. A similar comparison is made between firms that did not engage an auditor for some type of service (ASSURANCE=0) and firms that had their financial statements compiled by an auditor (ASSURANCE=1), between the 'compiled' firms (ASSURANCE=1) and the firms that had their annual accounts reviewed (ASSURANCE=2) and between the 'reviewed' firms (ASSURANCE=2) and the firms that actually demanded an audit (ASSURANCE=3). For firms that engage an auditor for some type of service, the average management ownership percentages differ insignificantly among the three assurance levels while the average level of leverage is found to be significantly higher for firms that had their annual accounts reviewed compared to those that had their annual accounts compiled. Panel B of table 2 presents the dichotomous variables and the proportion (relative frequencies) of the cases that are coded 1 for each variable. In this panel, we also compare the proportions of the firms that did not engage an auditor (ENGAGEMENT=0) with those that did (ENGAGEMENT=1) and a similar comparison is made between the firms that demand a different level of assurance. 
In table 3, we report the Pearson (below the diagonal) and Spearman (above the diagonal) correlations of the variables within our model. The correlations between management ownership and both auditor engagement and assurance are significantly negative, which is consistent with the first agency cost hypothesis. Contrary to the second agency cost hypothesis, leverage does not show significant correlations with the dependent variables. We further checked for multicollinearity using variance inflation factor analysis (VIF) and find all scores to be lower than 10 (the highest score was 2.54), indicating no problem of multicollinearity.

Insert table 3 about here

\subsection{Hypotheses tests}

Table 4 presents our logistic regression models (model 1 and 2) and ordered logistic regression models (model 3 and 4) related to the demand for auditor engagement and assurance respectively. The table presents the Beta coefficients of all explanatory and control variables, the robust standard errors, the Log likelihood statistic, the Chi-square statistic and three goodness of fit measures (Nagelkerke $\mathrm{R}^{2}$, McFadden $\mathrm{R}^{2}$ and Cox-Snell $\mathrm{R}^{2}$ ). All models are found to be significant $(p \leq 0.0011)$. The Nagelkerke pseudo $\mathrm{R}^{2}$ values of our engagement models ( 0.120 and 0.137 respectively) are similar to the corresponding statistics reported by Niskanen et al. (2010) and Carey et al. (2000), which range between 0.10 and 0.21.

Model 1 can be considered as our benchmark model as it is comparable to the models included in audit demand studies focusing on listed companies. Although the coefficient of MAN_OWN is negative in this model, indicating that higher management ownership leads to 
a lower demand for auditor engagement (due to the interest alignment effect), it is not significant. We argue that this might be due to the existence of a moderating effect of the generational stage of the family firm, as hypothesised in H1a. To test this, we included the moderating variable MAN_OWN*GENERATION in model 2. H1a is supported by our data as this model shows a significant negative coefficient for the variable MAN_OWN and a significant positive coefficient for the interaction variable MAN_OWN*GENERATION. The sum of the coefficients of both variables is positive, denoting that management ownership is positively related to auditor engagement (indicating an entrenchment effect) if the firm is in a subsequent generational stage. Management ownership thus only seems to be negatively associated with the demand for auditor engagement (indicating an interest alignment effect) in first generation private family firms.

Insert table 4 about here

Our results, however, do not support $\mathrm{H} 1 \mathrm{~b}$ since the coefficients of MAN_OWN and MAN_OWN*GENERATION are insignificant in model 4 . We thus only find a moderating effect of generation when we treat all auditor services the same while we find no effect when we allow separate intercepts for the different services.

Our regression results do not support $\mathrm{H} 2 \mathrm{a}$ as the coefficients of the variable LEVERAGE and the moderating variable LEVERAGE*GENERATION are insignificant in model 2. Although LEVERAGE is found to be significant in model 3 and 4, the moderating variable LEVERAGE*GENERATION remains insignificant and our results therefore provide no support for $\mathrm{H} 2 \mathrm{~b}$ either.

Table 5, which presents our multinomial logistic regression models, provides us with a more detailed view about how our explanatory variables relate to each auditor service 
separately. This table also presents the Beta coefficients of all explanatory and control variables, the robust standard errors, the Log pseudolikelihood statistic, the Chi-square statistic and three goodness of fit measures (Nagelkerke $\mathrm{R}^{2}, \mathrm{McFadden} \mathrm{R}^{2}$ and Cox-Snell $\mathrm{R}^{2}$ ). Both models are found to be significant $(p \leq 0.0003)$.

The first model corresponds to models 1 and 3 of table 4 and thus does not yet include GENERATION and the moderating variables MAN_OWN*GENERATION and LEVERAGE*GENERATION. The second model of table 5 corresponds to models 2 and 4 of table 4 and does include these variables. These multinomial logistic regression results give a more nuanced view of our findings with respect to ENGAGEMENT and ASSURANCE.

Insert table 5 about here

More specifically, although the results in table 5 (model 2) indicate that generation moderates the relationship between MAN_OWN and the probability of hiring an audit firm to prepare (compilation) or review financial statements (versus not hiring an audit firm at all), the coefficients of MAN_OWN and MAN_OWN*GENERATION are found to be insignificant for audits. This can be explained by the fact that passive family shareholders in private family firms are likely to be able to obtain insider information if necessary and therefore do not need audited financial statements. Since this insider information can be biased as well, however, they are likely to demand a review or compilation when shareholder-manager agency costs are high. Although the level of obtained assurance is lower for these services (a compilation even provides no explicit assurance but can provide some 
implicit assurance $^{12}$ (Johnson et al. 1983)), they seem to provide the passive family shareholders with a monitoring tool that is sufficiently effective in reducing the existing agency conflicts. Moreover, since audits are substantially more expensive than reviews and compilations (AICPA 2010), the demand for these lower assurance services could further be considered as a more cost-effective way to reduce shareholder-manager agency costs compared to demanding an audit in wholly family-owned private firms.

Higher levels of assurance, however, do seem important to debtholders since the coefficient of LEVERAGE is significant for audits while not being significant for compilations and reviews in model 1 of table 5. After including GENERATION and the moderating variables, the coefficient of LEVERAGE also becomes significant for reviews. For audits, the p-value (0.104) of LEVERAGE just decreases below the $10 \%$ significance threshold. In line with our logit and ordered logit regression results, we find no support for the moderating effect of generation on the demand for auditor services ( $\mathrm{H} 2 \mathrm{a}$ and $\mathrm{H} 2 \mathrm{~b}$ ). This may indicate that the aforementioned hazards of subsequent generation private family firms (e.g. incompetence of management, opportunism, etc.) not directly lead to higher agency costs of debt, possibly due to a reputation effect. Following Diamond (1989), who states that a good reputation is able to eliminate the conflicts of interest between borrowers and lenders

${ }^{12}$ Although the audit firm obtains or provides no explicit assurance in a compilation engagement, '...the CPA should develop an overall evaluation of the accounting information. This evaluation should be completed in the context of the CPA's understanding of the operating characteristics of the client and current economic conditions' (Madray 2008, p. 4.21). Moreover, '[i]n a compilation, the CPA must comply with Statements on Standards for Accounting and Review Services (SSARSs), which require the accountant to have an understanding of the industry in which the client operates, obtain knowledge about the client, and read the financial statements and consider whether such financial statements appear appropriate in form and free from obvious material errors' (AICPA 2010, p. 1). Therefore a compilation may provide some (implicit) assurance to the users of the financial statements. 
over time, subsequent generation private family firms may already have developed this good reputation. Due to this good reputation, debtholders will be less concerned about possible wealth transfers to shareholders, which might in turn lead to a lower demand for auditor assurance.

Concerning the control variables, we find, consistent with several other studies (Piot 2001, Broye and Weill 2008, Knechel et al. 2008, Francis et al. 2009, Niskanen et al. 2011), that the variable SIZE has a strongly significant positive coefficient in our logit and ordered logit models, denoting that there is a higher demand for both auditor engagement and assurance within larger firms. SIZE also has a significant positive coefficient in the multinomial logistic regression results for reviews and audits but not for compilations.

\subsection{Additional tests}

In order to test the robustness of our findings, we ran the regressions with other proxies for both the shareholder-manager and shareholder-debtholder agency conflicts (not tabulated). Instead of using management ownership to proxy for the possible agency conflicts between shareholders and managers, Niskanen et al. (2010) use ownership dispersion, defined as the natural logarithm of one plus the number of shareholders, as a measure for these agency costs. When replacing MAN_OWN in model 2 of table 4 with this proxy, the

results remained similar ${ }^{13}$. A significantly positive coefficient of LN_OWNERS ( $p$-value of 0.066) was found and the moderating variable LN_OWNERS*GENERATION was found to be significantly negative ( $p$-value of 0.075 ) and the sum of the coefficients of both variables was found to be negative. When replacing MAN_OWN with LN_OWNERS in the assurance models, its coefficient was found to be insignificant, which is also in line with our previous

\footnotetext{
${ }^{13}$ In order to be similar, the coefficients should switch signs as, in contrast to management ownership, higher ownership dispersion is considered to lead to more agency costs according to agency theory.
} 
results. When including LN_OWNERS in our multinomial logistic regressions, the results remain in line with our previous findings reported in model 2 of table 5 regarding compilations and audits. Only regarding reviews, the coefficients of LN_OWNERS and LN_OWNERS*GENERATION became insignificant when using this proxy for the shareholder-manager agency costs (p-value of 0.266 and 0.106 respectively).

As a majority ownership stake in a company might give managers an even higher possibility to expropriate passive family shareholders, we also replaced the variable MAN_OWN in model 2 of table 4 by CONTROLLING_MAN, a dummy equal to 1 if managers are the ultimate controlling shareholders. Results are in line with our previous findings as the coefficient of CONTROLLING_MAN was found to be negative and significant $(p$-value of 0.059), the interaction variable CONTROLLING_MAN*GENERATION was found to be significantly positive ( $p$-value of 0.034) and the sum of both coefficients was found to be positive as well. The coefficient of CONTROLLING_MAN was, also in line with our previous findings, found to be insignificant when replacing MAN_OWN with this proxy in the assurance models. When including CONTROLLING_MAN in model 2 of table 5, the results are also in accordance with our previous findings. In contrast to the previous robustness test, the moderating variable CONTROLLING_MAN*GENERATION becomes significantly positive again regarding reviews (p-value of 0.008) although CONTROLLING_MAN remains insignificant (p-value of 0.167).

Our findings reported in section 4.2 might also be a consequence of nonlinearities in the 'management ownership - auditor services demand' relationship only ${ }^{14}$, as suggested by Lennox (2005). The fact that the mean value of management ownership is significantly

\footnotetext{
${ }^{14}$ We thank an anonymous reviewer for raising this issue.
} 
higher for first generation firms compared to subsequent generation firms (see table 2, panel A) might also be an indication for such nonlinearities. Therefore we followed the same method (and used the same management ownership thresholds) as Lennox (2005) to examine this possibility and also tested a model with the variables MAN_OWN, MAN_OWN² and MAN_OWN³ . We, however, found no evidence of nonlinearities in the 'management ownership - auditor services demand' relationship.

Moreover, instead of defining LEVERAGE as total debt to total assets, several studies also proxy for the agency conflicts between shareholders and debtholders by defining LEVERAGE as long-term debt divided by total assets (e.g. Piot 2001, Fan and Wong 2005). The findings remain consistent with our previous results when using this alternative definition, as the coefficient of LONGTERMDEBT was found to be positive and significant in the assurance models of table 4 ( $p$-value of 0.035 and 0.091 respectively) while being insignificant in the engagement models. When including this proxy in the multinomial logistic regression model (model 2 of table 5), the coefficient of this proxy becomes significantly negative regarding compilations ( $p$-value of 0.075 ) while being insignificant regarding the other services. This implies that an increase in long-term debt decreases the likelihood that an audit firm is hired to prepare the financial statements. Whether this is due to the fact the debtholders require higher levels of assurance about the validity of the financial statements, as indicated by the ordered logit results, cannot be deduced from these results and thus needs further examination.

Related to the control variables, we mentioned in section 3.1 that we excluded 143 cases due to a missing value for the variable QUICK. In order to be sure that the removal of these cases did not distort our results, we ran our models again without the removal of these cases and without the variable QUICK. The results remained similar to our previous findings. 
Finally, with respect to our measure of GENERATION, we consider both purchased firms and firms established by the current owners to be first generation family firms. However, one could argue that descendants can buy the firm from their parents as well, which might make some of the purchased firms to be incorrectly classified as first generation family firms. As the survey does not include information about the seller(s) of the firm, we eliminated all cases in which the family firm was purchased (125 observations) and ran the regressions again. The results remained in line with our previous findings.

\section{Conclusions}

Unlike former audit demand studies (Carey et al. 2000, Collis et al. 2004, Niskanen et al. 2010, Niemi et al. 2012), which consider wholly family-owned private firms as a homogeneous group of firms that incur a minimal level of agency costs, we focus on the heterogeneity of this particular type of firms and examine the moderating effect of generational stage within the auditor services demand functions of these firms.

Our results suggest that the frequently found negative association between management ownership, which proxies for the agency conflicts between owners and managers, and auditor services demand does not hold for all private family firms. Following the view of several family firm scholars (Gomez-Mejia et al. 2001, Schulze et al. 2001, Schulze et al. 2003b, Poza et al. 2004, Blanco-Mazagatos et al. 2007) on agency costs within private family firms, we hypothesised that the interest alignment effect, and thus the negative association, only prevails in first generation private family firms while having a predominating entrenchment effect in subsequent generation private family firms. In contrast to founders, whose altruistic feelings towards their family will lead them to take into account the needs of all family members, descendants will prioritise the interests of their own immediate families (Blanco-Mazagatos et al. 2007). Due to a diminishing feeling of altruism 
towards their extended family, they may be more inclined to mis(use) their discretion over the firm's assets to achieve their own (immediate family) goals while ignoring the interests of other family shareholders. Due to this entrenching behaviour, higher management shareholdings will lead to higher shareholder-manager agency costs in subsequent generation private family firms and therefore a higher demand for auditor services.

In order to test this hypothesis in the specific context of US private (family) firms, which have no audit requirement, we consider auditor services as a broad concept that includes audits, reviews and compilations as they could all be considered as agency cost reducing devices. More specifically, we examined the demand for both auditor engagement, which we defined as having any form of engagement with an auditor, and auditor assurance, which takes into account the different levels of assurance of an audit, a review and a compilation. Our results support our hypothesis, but only when including auditor engagement as dependent variable. Although we hypothesised a similar relationship when including auditor assurance as dependent variable, this hypothesis was not supported. A more detailed analysis based on multinomial logistic regressions, in which we examine the demand for each auditor service separately, reveals that our hypothesis is only supported regarding compilations and reviews but not regarding audits. Since passive family shareholders in private family firms are likely to be able to get insider information if necessary, they may therefore not require an audit (by which a high level of assurance is obtained about the validity of the financial statements) to reduce the level of shareholder-manager agency costs. However, as this insider information can be biased as well, our results suggest that passive family shareholders are likely to demand a compilation or a review when shareholdermanager agency costs are high. Even though a lower level of assurance is obtained by these services, they seem to provide the passive family shareholders with a monitoring tool that is sufficiently effective in reducing the existing agency conflicts. Moreover, the demand for 
these lower assurance services could further be considered as a more cost-effective way to reduce shareholder-manager agency costs in wholly family-owned private firms compared to demanding an audit.

When considering the shareholder-debtholder agency relationship, a high level of assurance does seem important to mitigate the related agency costs since leverage, which proxies for the agency conflicts between shareholders and debtholders, was found to be significantly positively associated with auditor assurance and not with auditor engagement. The multinomial results generally confirm this since leverage was only found to have a positive effect on the probability of demanding an audit and review (versus not hiring an auditor at all), being the services with the highest level of assurance. Although hypothesised, generational stage was not found to have a moderating role in this relationship. The increase in shareholder-debtholder agency costs due to the aspects related to subsequent generation private family firms (e.g. possible absence of a long-term perspective, incompetence of management due to adverse selection, etc.) may therefore be mitigated by an offsetting firm reputation effect.

Overall, we believe that this study makes several contributions to both practice and theory. Its main theoretical contribution lies in linking the family firm literature with the audit demand literature. Although family firms are often considered to be a homogeneous group in the audit literature, family firm literature clearly indicates that family firms should be studied as a heterogeneous group of ventures. Agency costs do exist in private family firms but the extent depends on the type of family firm. Therefore, it is necessary to study this heterogeneity in order to grasp what actually determines auditor services demand in private family firms. Several family characteristics and their resulting impact on agency costs, of which the generational stage of a family firm is one aspect, could for example explain why Collis et al. (2004) found that wholly family-owned private firms were significantly 
negatively associated with audit demand while Collis (2012) did not find a significant association. Although Carey et al. (2000) and Niskanen et al. (2010) already provided some interesting insights related to audit demand in private family firms, they generally focused on the agency conflicts between family and non-family owners/managers and therefore did not elaborate on the agency conflicts existing between active shareholder-managers and passive family shareholders. We did examine this particular type of agency conflicts and argued that they might be mitigated by auditor services as well.

In addition, considering these auditor services as a broader concept, including reviews and compilations, led to a more nuanced view about auditor services demand. More specifically, the services for which less assurance is obtained seem effective substitutes to reduce the level of shareholder-manager agency costs (at least in a wholly family-owned private firm context) but not to reduce the level of shareholder-debtholder agency costs. Examining why this difference exists might be very interesting for both theorists and practitioners. For theorists, the answer to this question might reveal a new dimension of what actually determines audit demand. Auditors, on the other hand, might be better able to provide the services the clients actually need and can therefore reduce the expectation gap when knowing the answer to this question.

Due to the specific context in which we tested our hypotheses, one must be careful when generalising our results or comparing them with others. More specifically, most audit demand studies that focus on private firms were set in a European context in which most small companies are required to publish their financial statements. The complete set of determinants of audit demand might therefore differ between US and European private family firms. However, revealing the complete audit demand function of wholly familyowned private firms is not the goal of this study, which is restricted to examining the 
moderating role of generation on the 'intra-family related agency conflicts - auditor services demand' relationship.

There are some limitations associated with this study, indicating possibilities for future research. One important limitation is the age of our data, which was collected prior to the financial crisis. However, as this study focuses on the influence of agency conflicts on auditor services demand and the moderating role of generation on this relationship, there is no indication which suggests that the found relationships are not stable over time. Agency conflicts will arise in good and bad economic conditions as both principals and agents want to maximise their personal wealth. We do recognise, however, that the financial crisis might have shifted the demand curve(s) upwards or downwards, even if the level of agency conflicts remained similar. Therefore, we only focused on the direction and significance of the coefficients in our models without trying to provide numerical estimations of the extent to which agency conflicts influence auditor services demand. Another limitation relates to the fact that we were not able to actually control for the differences in costs between audits, reviews and compilations. Finally, by including GENERATION as moderating variable, we were only partly able to take into account the heterogeneity of private family firms since the use of this variable assumes family firms that are in the same generational stage to be similar, which may not always be the case.

We hope that our study will encourage other audit researchers to focus more on how to better grasp this heterogeneity of private family firms and the specific context in which they are operating in order to develop the audit demand literature further. 


\section{References}

Abdel-Khalik, A.R., 1993. Why Do Private Companies Demand Auditing? A Case for Organizational Loss of Control. Journal of Accounting, Auditing \& Finance, 8 (1), $31-52$.

Aicpa, 2010. What Is the Difference Between a Compilation, a Review and an Audit? Comparative Overview.

Allee, K.D. and Yohn, T.L., 2009. The Demand for Financial Statements in an Unregulated Environment: An Examination of the Production and Use of Financial Statements by Privately Held Small Businesses. Accounting Review, 84 (1), 1-25.

Anderson, R.C., Mansi, S.A. and Reeb, D.M., 2003. Founding family ownership and the agency cost of debt. Journal of Financial Economics, 68 (2), 263-285.

Ang, J.S., Cole, R.A. and Lin, J.W., 2000. Agency Costs and Ownership Structure. Journal of Finance, 55 (1), 81-106.

Becker, C.L., Defond, M.L., Jiambalvo, J. and Subramanyam, K.R., 1998. The Effect of Audit Quality on Earnings Management. Contemporary Accounting Research, 15 (1), $1-24$.

Becker, G.S., 1981. A Treatise on the Family. Cambridge: Harvard University Press.

Blackwell, D.W., Noland, T.R. and Winters, D.B., 1998. The Value of Auditor Assurance: Evidence from Loan Pricing. Journal of Accounting Research, 36 (1), 57-70.

Blanco-Mazagatos, V., De Quevedo-Puente, E. and Castrillo, L.A., 2007. The Trade-Off Between Financial Resources and Agency Costs in the Family Business: An Exploratory Study. Family Business Review, 20 (3), 199-213.

Broye, G. and Weill, L., 2008. Does leverage influence auditor choice? A cross-country analysis. Applied Financial Economics, 18 (9), 715-731.

Burkart, M., Panunzi, F. and Shleifer, A., 2003. Family Firms. Journal of Finance, 58 (5), 2167-2202.

Carey, P., Simnett, R. and Tanewski, G., 2000. Voluntary Demand for Internal and External Auditing by Family Businesses. Auditing: A Journal of Practice \& Theory, 19 (1), $37-$ 51.

Chow, C.W., 1982. The Demand for External Auditing: Size, Debt and Ownership Influences. Accounting Review, 57 (2), 272-291.

Chrisman, J.J., Chua, J.H., Kellermanns, F.W. and Chang, E.P.C., 2007. Are family managers agents or stewards? An exploratory study in privately held family firms. Journal of Business Research, 60 (10), 1030-1038. 
Chrisman, J.J., Chua, J.H. and Litz, R.A., 2004. Comparing the Agency Costs of Family and Non-Family Firms: Conceptual Issues and Exploratory Evidence. Entrepreneurship: Theory \& Practice, 28 (4), 335-354.

Collis, J., 2012. Determinants of voluntary audit and voluntary full accounts in micro- and non-micro small companies in the UK. Accounting and Business Research, 42 (4), 441-468.

Collis, J., Jarvis, R. and Skerratt, L., 2004. The demand for the audit in small companies in the UK. Accounting \& Business Research, 34 (2), 87-100.

Cui, H. and Mak, Y.T., 2002. The relationship between managerial ownership and firm performance in high R\&D firms. Journal of Corporate Finance, 8 (4), 313-336.

Daily, C.M. and Dollinger, M.J., 1992. An empirical examination of ownership structure in family and professionally managed firms. Family Business Review, 5 (2), 117-136.

Defond, M.L., 1992. The Association Between Changes in Client Firm Agency Costs and Auditor Switching. Auditing: A Journal of Practice \& Theory, 11 (1), 16-31.

Diamond, D.W., 1989. Reputation Acquisition in Debt Markets. Journal of Political Economy, 97 (4), 828-862.

Fama, E.F. and Jensen, M.C., 1983. Separation of Ownership and Control. Journal of Law \& Economics, 26 (2), 301-326.

Fan, J.P.H. and Wong, T.J., 2005. Do External Auditors Perform a Corporate Governance Role in Emerging Markets? Evidence from East Asia. Journal of Accounting Research, 43 (1), 35-72.

Firth, M. and Smith, A., 1992. Selection of auditor firms by companies in the new issue market. Applied Economics, 24 (2), 247-255.

Francis, J.R., Richard, C. and Vanstraelen, A., 2009. Assessing France's Joint Audit Requirement: Are Two Heads Better than One? Auditing: A Journal of Practice \& Theory, 28 (2), 35-63.

Francis, J.R. and Wilson, E.R., 1988. Auditor Changes: A Joint Test of Theory Relating to Agency Costs and Auditor Differentiation. Accounting Review, 63 (4), 663-682.

Gomez-Mejia, L.R., Nuñez-Nickel, M. and Gutierrez, I., 2001. The Role of Family Ties in Agency Contracts. Academy of Management Journal, 44 (1), 81-95.

Hay, D. and Davis, D., 2004. The Voluntary Choice of an Auditor of Any Level of Quality. Auditing: A Journal of Practice \& Theory, 23 (2), 39-55.

Hope, O.-K., Langli, J.C. and Thomas, W.B., 2012. Agency conflicts and auditing in private firms. Accounting, Organizations and Society, 37 (7), 500-517.

Hosmer, D.W. and Lemeshow, S., 2000. Applied Logistic Regression. 2nd ed. New York: Wiley. 
James, H.S., 1999. Owner as Manager, Extended Horizons and the Family Firm. International Journal of the Economics of Business, 6 (1), 41-55.

Jensen, M.C. and Meckling, W.H., 1976. Theory of the Firm: Managerial Behavior, Agency Costs and Ownership Structure. Journal of Financial Economics, 3 (4), 305-360.

Johnson, D.A., Pany, K. and White, R., 1983. Audit Reports and the Loan Decision: Actions and Perceptions. Auditing, 2 (2), 38.

Karra, N., Tracey, P. and Phillips, N., 2006. Altruism and Agency in the Family Firm: Exploring the Role of Family, Kinship, and Ethnicity. Entrepreneurship: Theory \& Practice, 30 (6), 861-877.

Kim, J.-B., Simunic, D.A., Stein, M.T. and Yi, C.H., 2011. Voluntary Audits and the Cost of Debt Capital for Privately Held Firms: Korean Evidence. Contemporary Accounting Research, 28 (2), 585-615.

Knechel, W.R., Niemi, L. and Sundgren, S., 2008. Determinants of Auditor Choice: Evidence from a Small Client Market. International Journal of Auditing, 12 (1), 65-88.

Lennox, C., 2005. Management Ownership and Audit Firm Size. Contemporary Accounting Research, 22 (1), 205-227.

Lubatkin, M.H., Schulze, W.S., Ling, Y. and Dino, R.N., 2005. The effects of parental altruism on the governance of family-managed firms. Journal of Organizational Behavior, 26 (3), 313-330.

Lunati, M.T., 1997. Ethical issues in economics: From altruism to cooperation to equity. London: Macmillan Press.

Madray, J.R., 2008. Compilations \& Reviews. Chicago: CCH.

Mcconnell, J.J. and Servaes, H., 1990. Additional evidence on equity ownership and corporate value. Journal of Financial Economics, 27 (2), 595-612.

Miller, D. and Le Breton-Miller, I., 2006. Family Governance and Firm Performance: Agency, Stewardship, and Capabilities. Family Business Review, 19 (1), 73-87.

Minnis, M., 2011. The Value of Financial Statement Verification in Debt Financing: Evidence from Private U.S. Firms. Journal of Accounting Research, 49 (2), 457-506.

Morck, R., Shleifer, A. and Vishny, R.W., 1988. Management ownership and market valuation: An empirical analysis. Journal of Financial Economics, 20, 293-315.

Niemi, L., Kinnunen, J., Ojala, H. and Troberg, P., 2012. Drivers of voluntary audit in Finland: to be or not to be audited? Accounting and Business Research, 42 (2), 169196.

Niskanen, M., Karjalainen, J. and Niskanen, J., 2010. The Role of Auditing in Small, Private Family Firms: Is It About Quality and Credibility? Family Business Review, 23 (3), 230-245. 
Niskanen, M., Karjalainen, J. and Niskanen, J., 2011. Demand for Audit Quality in Private Firms: Evidence on Ownership Effects. International Journal of Auditing, 15 (1), 4365.

Piot, C., 2001. Agency costs and audit quality: evidence from France. European Accounting Review, 10 (3), 461-499.

Pittman, J.A. and Fortin, S., 2004. Auditor choice and the cost of debt capital for newly public firms. Journal of Accounting and Economics, 37 (1), 113-136.

Poza, E.J., Hanlon, S. and Kishida, R., 2004. Does the Family Business Interaction Factor Represent a Resource or a Cost? Family Business Review, 17 (2), 99-118.

Reed, B.J., Trombley, M.A. and Dhaliwal, D.S., 2000. Demand for Audit Quality: The Case of Laventhol and Horwath's Auditees. Journal of Accounting, Auditing \& Finance, 15 (2), 183-198.

Schulze, W.S., Lubatkin, M.H. and Dino, R.N., 2003a. Exploring the Agency Consequences of Ownership Dispersion Among the Directors of Private Family Firms. Academy of Management Journal, 46 (2), 179-194.

Schulze, W.S., Lubatkin, M.H. and Dino, R.N., 2003b. Toward a theory of agency and altruism in family firms. Journal of Business Venturing, 18 (4), 473-490.

Schulze, W.S., Lubatkin, M.H., Dino, R.N. and Buchholtz, A.K., 2001. Agency Relationships in Family Firms: Theory and Evidence. Organization Science, 12 (2), 99-116.

Short, H. and Keasey, K., 1999. Managerial ownership and the performance of firms: Evidence from the UK. Journal of Corporate Finance, 5 (1), 79-101.

Stark, O., 1995. Altruism and beyond: An economic analysis of transfers within families and groups. Cambridge: Cambridge University Press.

Van Den Berghe, L.a.A. and Carchon, S., 2003. Agency Relations within the Family Business System: an exploratory approach. Corporate Governance: An International Review, 11 (3), 171-179.

Villalonga, B. and Amit, R., 2006. How do family ownership, control and management affect firm value? Journal of Financial Economics, 80 (2), 385-417. 
Table 1. Definition of variables

\begin{tabular}{|c|c|}
\hline Variable & Definition \\
\hline \multirow{3}{*}{$\begin{array}{l}\text { Dependent variables: } \\
\text { ENGAGEMENT } \\
\text { ASSURANCE }\end{array}$} & \\
\hline & Whether the firm's financial statements are audited, reviewed or compiled $(1,0)$ \\
\hline & $\begin{array}{l}\text { The level of auditor assurance that was demanded by the firm ( } 3=\text { audit; } 2=\text { review; } \\
1=\text { compilation; } 0=\text { no assurance) }\end{array}$ \\
\hline \multirow{2}{*}{$\begin{array}{l}\text { Explanatory variables: } \\
\text { MAN_OWN }\end{array}$} & \\
\hline & $\begin{array}{l}\text { The sum of ownership percentages of the top three owners of the firm who also } \\
\text { manage it. }\end{array}$ \\
\hline \multirow{2}{*}{$\begin{array}{l}\text { GENERATION } \\
\text { LEVERAGE }\end{array}$} & Whether the family firm is a subsequent generation private family firm $(1,0)$ \\
\hline & Total debt to total assets \\
\hline \multicolumn{2}{|l|}{ Control variables: } \\
\hline \multirow{2}{*}{$\begin{array}{l}\text { ROA } \\
\text { OUICK }\end{array}$} & Income after expenses and taxes to total assets \\
\hline & Current assets minus inventory to current liabilities \\
\hline \multirow{2}{*}{$\begin{array}{l}\text { DISTRESS } \\
\text { SIZE }\end{array}$} & Whether the total amount of the firm's equity is negative $(1,0)$ \\
\hline & The natural logarithm of total assets \\
\hline \multirow{3}{*}{$\begin{array}{l}\text { LIMITED } \\
\text { INDUSTRY_1 } \\
\text { INDUSTRY_2 }\end{array}$} & Whether the firm is organised with limited liability for the owners $(1,0)$ \\
\hline & Whether the firm is part of the mining or construction industry $(1,0)$ \\
\hline & $\begin{array}{l}\text { Whether the firm is part of the manufacturing industry with SIC code between } 20 \\
\text { and } 29(1,0)\end{array}$ \\
\hline INDUSTRY_3 & $\begin{array}{l}\text { Whether the firm is part of the manufacturing industry with SIC code between } 30 \\
\text { and } 40(1,0)\end{array}$ \\
\hline \multirow{4}{*}{$\begin{array}{l}\text { INDUSTRY_4 } \\
\text { INDUSTRY_5 } \\
\text { INDUSTRY_6 } \\
\text { INDUSTRY_7 }\end{array}$} & Whether the firm is part of the transportation or public utilities industry $(1,0)$ \\
\hline & Whether the firm is part of the wholesale trade industry $(1,0)$ \\
\hline & Whether the firm is part of the finance, insurance or real estate industry $(1,0)$ \\
\hline & $\begin{array}{l}\text { Whether the firm is part of the services industry with SIC code between } 70 \text { and } 79 \\
(1,0)\end{array}$ \\
\hline INDUSTRY_8 & $\begin{array}{l}\text { Whether the firm is part of the services industry with SIC code between } 80 \text { and } 90 \\
(1,0)\end{array}$ \\
\hline
\end{tabular}


Table 2. Descriptive statistics

Panel A. Continuous variables

\begin{tabular}{|c|c|c|c|c|c|c|c|c|c|c|c|c|c|c|c|}
\hline & & & & & & \multicolumn{3}{|c|}{ GENERATION (first/subsequent) } & \multicolumn{7}{|c|}{ ENGAGEMENT (yes/no) } \\
\hline \multirow{8}{*}{$\begin{array}{l}\text { Variable } \\
\text { MAN_OWN } \\
\text { LEVERAGE } \\
\text { ROA } \\
\text { QUICK } \\
\text { SIZE } \\
\text { ASSETS (in } \\
\text { millions) }\end{array}$} & & & & & & First $(0)$ & Subs. (1) & (1) vs. (0) & \multicolumn{3}{|c|}{ No $(n=163)$} & \multicolumn{3}{|c|}{ Yes $(n=319)$} & 'yes' vs. 'no' \\
\hline & Min & $\operatorname{Max}$ & Median & Mean & s.d. & Mean & Mean & P-Value & Median & Mean & s.d. & Median & Mean & s.d. & p-Value \\
\hline & 0.00 & 100.00 & 100.00 & 73.72 & 34.26 & 75.08 & 62.44 & $0.012 * *$ & 100.00 & 79.96 & 31.03 & 99.00 & 70.53 & 35.41 & $0.004 * * *$ \\
\hline & 0.01 & 8.28 & 0.54 & 0.72 & 0.99 & 0.72 & 0.66 & 0.678 & 0.45 & 0.70 & 0.98 & 0.57 & 0.72 & 1.00 & 0.835 \\
\hline & -3.88 & 17.20 & 0.17 & 0.68 & 2.09 & & & & 0.23 & 0.88 & 2.43 & 0.15 & 0.57 & 1.90 & 0.121 \\
\hline & 0.05 & 213.81 & 2.34 & 10.52 & 29.47 & & & & 2.64 & 10.67 & 30.13 & 2.10 & 10.45 & 29.18 & 0.940 \\
\hline & 8.10 & 17.47 & 13.72 & 13.48 & 2.03 & & & & 12.92 & 12.79 & 2.01 & 14.03 & 13.83 & 1.95 & $<0.001 * * *$ \\
\hline & 0.01 & 88.30 & 0.91 & 3.52 & 8.27 & & & & 0.41 & 1.80 & 3.85 & 1.24 & 4.41 & 9.68 & $0.001 * * *$ \\
\hline & & & & & & & & & & & & & & & \\
\hline
\end{tabular}

$\mathrm{N}=482 ; *, * *, * * *$ indicate significance at the $10 \%, 5 \%$ and $1 \%$ levels respectively (two-tailed); ASSETS is defined as the untransformed value of total assets (in millions); See table 1 for the definitions of the other variables.

\begin{tabular}{|c|c|c|c|c|c|c|c|c|c|c|c|c|}
\hline \multirow{9}{*}{$\begin{array}{l}\text { Variable } \\
\text { MAN_OWN } \\
\text { LEVERAGE } \\
\text { ROA } \\
\text { QUICK } \\
\text { SIZE } \\
\text { ASSETS (in } \\
\text { millions) }\end{array}$} & \multicolumn{12}{|c|}{ ASSURANCE ( $0=$ no assurance, $1=$ compilation, $2=$ review, $3=$ audit $)$} \\
\hline & \multicolumn{3}{|c|}{ Compilation $(1)(n=74)$} & \multicolumn{3}{|c|}{ Review $(2)(\mathrm{n}=101)$} & \multicolumn{3}{|c|}{ Audit $(3)(n=144)$} & \multirow{2}{*}{$\begin{array}{c}\text { (1) versus }(0) \\
p \text {-Value }\end{array}$} & \multirow{2}{*}{$\begin{array}{c}\text { (2) versus (1) } \\
p \text {-Value }\end{array}$} & \multirow{2}{*}{$\begin{array}{c}\text { (3) versus (2) } \\
p \text {-Value }\end{array}$} \\
\hline & Median & Mean & s.d. & Median & Mean & s.d. & Median & Mean & s.d. & & & \\
\hline & 95.00 & 69.18 & 36.15 & 88.00 & 69.19 & 35.71 & 100.00 & 72.17 & 35.00 & $0.020 * *$ & 0.998 & 0.516 \\
\hline & 0.55 & 0.57 & 0.46 & 0.58 & 0.88 & 1.30 & 0.55 & 0.70 & 0.95 & 0.252 & $0.053^{*}$ & 0.223 \\
\hline & 0.23 & 0.51 & 0.99 & 0.11 & 0.69 & 2.03 & 0.14 & 0.51 & 2.15 & 0.206 & 0.476 & 0.504 \\
\hline & 2.38 & 10.90 & 29.02 & 2.14 & 8.02 & 23.97 & 2.06 & 11.92 & 32.48 & 0.955 & 0.473 & 0.306 \\
\hline & 13.52 & 13.49 & 1.65 & 14.42 & 14.06 & 1.96 & 14.02 & 13.84 & 2.07 & $0.009 * * *$ & $0.046^{* * *}$ & 0.413 \\
\hline & 0.74 & 2.28 & 3.70 & 1.84 & 4.22 & 6.43 & 1.23 & 5.63 & 13.00 & 0.370 & $0.021 * *$ & 0.312 \\
\hline
\end{tabular}

$\mathrm{N}=482 ; *, * *, * * *$ indicate significance at the $10 \%, 5 \%$ and $1 \%$ levels respectively (two-tailed); ASSETS is defined as the untransformed value of total assets (in millions);

See table 1 for the definitions of the other variables. 


\begin{tabular}{|c|c|c|c|c|c|c|c|c|c|c|}
\hline & \multirow[b]{2}{*}{$\mathrm{N}=482$} & \multicolumn{3}{|c|}{ ENGAGEMENT (yes/no) } & \multicolumn{6}{|c|}{ ASSURANCE $(0=$ no assurance, $1=$ compilation, $2=$ review, $3=$ audit $)$} \\
\hline & & No $(n=163)$ & Yes $(n=319)$ & 'yes' vs. 'no' & $\begin{array}{l}\text { Compilation (1) } \\
(\mathrm{n}=74)\end{array}$ & $\begin{array}{l}\text { Review (2) } \\
(\mathrm{n}=101)\end{array}$ & $\begin{array}{l}\text { Audit (3) } \\
(\mathrm{n}=144)\end{array}$ & (1) vs. (0) & (2) vs. (1) & (3) vs. (2) \\
\hline Variable & Prop. & Prop. & Prop. & p-Value & Prop. & Prop. & Prop. & p-Value & p-Value & p-Value \\
\hline GENERATION & 0.11 & 0.07 & 0.13 & $0.041 * *$ & 0.11 & 0.15 & 0.13 & 0.286 & 0.435 & 0.596 \\
\hline DISTRESS & 0.17 & 0.18 & 0.16 & 0.561 & 0.16 & 0.22 & 0.13 & 0.683 & 0.358 & 0.053 \\
\hline LIMITED & 0.85 & 0.82 & 0.87 & 0.127 & 0.82 & 0.90 & 0.87 & 0.877 & 0.138 & 0.432 \\
\hline INDUSTRY_1 & 0.11 & 0.13 & 0.10 & 0.254 & 0.08 & 0.10 & 0.11 & 0.234 & 0.684 & 0.762 \\
\hline INDUSTRY_2 & 0.05 & 0.06 & 0.05 & 0.502 & 0.03 & 0.03 & 0.07 & 0.264 & 0.916 & 0.172 \\
\hline INDUSTRY_3 & 0.09 & 0.05 & 0.12 & $0.017 * *$ & 0.05 & 0.14 & 0.13 & 0.871 & $0.069 *$ & 0.880 \\
\hline INDUSTRY_4 & 0.05 & 0.02 & 0.07 & $0.053^{*}$ & 0.08 & 0.09 & 0.04 & $0.045^{* *}$ & 0.851 & 0.127 \\
\hline INDUSTRY_5 & 0.32 & 0.28 & 0.33 & 0.263 & 0.45 & 0.34 & 0.27 & 0.013 & 0.142 & 0.268 \\
\hline INDUSTRY_6 & 0.06 & 0.06 & 0.06 & 0.938 & 0.04 & 0.02 & 0.10 & 0.514 & 0.416 & $0.016 * *$ \\
\hline INDUSTRY_7 & 0.18 & 0.23 & 0.15 & $0.047 * *$ & 0.14 & 0.19 & 0.14 & 0.100 & 0.352 & 0.300 \\
\hline INDUSTRY_8 & 0.14 & 0.16 & 0.13 & 0.303 & 0.14 & 0.10 & 0.14 & 0.628 & 0.458 & 0.349 \\
\hline
\end{tabular}

$\mathrm{N}=482 ; * * *, * * *$ indicate significance at the $10 \%, 5 \%$ and $1 \%$ levels respectively (two-tailed); For variable definitions, see table 1.

Notes: This table presents the descriptive statistics of the variables used to test our hypotheses. Panel A presents the minima, maxima, medians, means and standard deviations of the continuous variables (ASSETS, defined as the untransformed value of total assets (in millions) is also included). Moreover, this panel presents the mean of the variable MAN_OWN and LEVERAGE for both first and subsequent generation private family firms and also presents the $p$-values of the mean-comparison t-tests. We also compare the means of each continuous variable between firms that engaged an audit firm for some type of auditor service (ENGAGEMENT=1) and firms that did not $($ ENGAGEMENT $=0$ ). A similar comparison is made between firms that did not engage an auditor (ASSURANCE $=0$, please remark that this is equal to ENGAGEMENT=0 and details for this particular group are therefore not mentioned in the 'assurance' section of the table) and firms that had their financial statements compiled by an auditor (ASSURANCE=1), between the 'compiled' firms (ASSURANCE=1) and the firms that had their annual accounts reviewed (ASSURANCE=2) and between the 'reviewed' firms (ASSURANCE=2) and the firms that actually demanded an audit (ASSURANCE=3).

Panel B presents the dichotomous variables and the proportion (relative frequencies) of the cases that are coded 1 for each variable. We compare the proportions of the firms that did not engage an auditor (ENGAGEMENT=0) with those that did (ENGAGEMENT=1) and a similar comparison is made between the firms that demand a different level of assurance. 
Table 3. Correlation matrix (Pearson correlations below the diagonal, Spearman correlations above the diagonal)

\begin{tabular}{|c|c|c|c|c|c|c|c|c|c|c|c|c|c|c|c|c|c|c|}
\hline Variable & 1 & 2 & 3 & 4 & 5 & 6 & 7 & 8 & 9 & 10 & 11 & 12 & 13 & 14 & 15 & 16 & 17 & 18 \\
\hline 1. ENGAGEMENT & 1 & $.85 * * *$ & $-.13 * * *$ & $.09 * *$ & .03 & $-.10 * *$ & -.02 & -.03 & $.24 * * *$ & .07 & -.05 & -.03 & $.11^{* *}$ & $.09 *$ & .05 & .00 & $-.09 * *$ & -.05 \\
\hline 2. ASSURANCE & $.85 * * *$ & 1 & $-.08^{*}$ & $.08^{*}$ & .04 & $-.12 * * *$ & -.02 & -.05 & $.23 * * *$ & .07 & -.03 & .01 & $.13 * * *$ & .04 & -.02 & .05 & $-.08 *$ & -.03 \\
\hline 3. MAN_OWN & $-.13 * * *$ & $-.09 * *$ & 1 & $-.12 * * *$ & -.03 & $.14 * * *$ & $.13 * * *$ & .07 & $-.30 * * *$ & $-.20 * * *$ & $.08 *$ & $-.08 *$ & $-.11 * *$ & -.01 & -.07 & $.11 * *$ & .00 & $.09 * *$ \\
\hline 4. GENERATION & $.09 * *$ & $.08^{*}$ & $-.11 * *$ & 1 & -.06 & $-.09 * *$ & -.01 & -.03 & $.22 * * *$ & $.11^{* *}$ & .00 & -.05 & $.16^{* * *}$ & .07 & .04 & -.06 & -.07 & $-.08 *$ \\
\hline 5. LEVERAGE & .01 & .02 & .04 & -.02 & 1 & $-.16 * * *$ & $-.54 * * *$ & $.65 * * *$ & .00 & $.18 * * *$ & .01 & .04 & -.05 & .06 & .07 & -.06 & .04 & $-.12 * *$ \\
\hline 6. ROA & -.07 & -.06 & $.11 * *$ & $-.08 *$ & $.16^{* * *}$ & 1 & $.13 * * *$ & -.07 & $-.25 * * *$ & $-.19 * * *$ & $.12 * * *$ & -.03 & -.02 & $-.12 * *$ & -.03 & .03 & -.06 & $.08^{*}$ \\
\hline 7. QUICK & -.00 & .01 & $.10 * *$ & -.04 & $-.12 * * *$ & .00 & 1 & $-.30 * * *$ & $-.15 * * *$ & $-.16^{* * * *}$ & $.09 * *$ & -.06 & -.01 & -.02 & $-.23 * * *$ & .02 & .05 & $.22 * * *$ \\
\hline 8. DISTRESS & -.03 & -.05 & $.10 * *$ & -.03 & $.63 * * *$ & $.08^{*}$ & $-.10 * *$ & 1 & $-.18 * * *$ & .05 & .01 & .02 & -.03 & .07 & -.05 & -.02 & .05 & -.02 \\
\hline 9. SIZE & $.24 * * *$ & $.23 * * *$ & $-.29 * * *$ & $.21 * * *$ & $-.22 * * *$ & $-.28 * * *$ & $-.12 * * *$ & $-.19 * * *$ & 1 & $.37 * * *$ & -.03 & $.10^{* *}$ & $.21 * * *$ & $.09 * *$ & $.15 * * *$ & $-.12 * *$ & $-.15 * * *$ & $-.24 * * *$ \\
\hline 10. LIMITED & .07 & .07 & $-.18 * * *$ & $.11^{* *}$ & $.10 * *$ & -.07 & $-.11 * *$ & .05 & $.39 * * *$ & 1 & .00 & -.01 & $.09^{* *}$ & $.10 * *$ & .07 & -.07 & -.05 & $-.14 * * *$ \\
\hline 11. INDUSTRY_1 & -.05 & -.03 & .07 & .00 & .00 & $.11 * *$ & $.12 * * *$ & .01 & -.03 & .00 & 1 & $-.08 *$ & $-.11 * *$ & $-.08 *$ & $-.24 * * *$ & $-.09 * *$ & $-.17 * * *$ & $-.14 * * *$ \\
\hline 12. INDUSTRY_2 & -.03 & .01 & $-.08^{*}$ & -.05 & -.01 & -.05 & -.06 & .02 & $.10 * *$ & -.01 & $-.08 *$ & 1 & $-.08^{*}$ & -.05 & $-.16^{* * *}$ & -.06 & $-.11 * *$ & $-.09 * *$ \\
\hline 13. INDUSTRY_3 & $.11 * *$ & $.13^{* * * *}$ & $-.10 * *$ & $.16^{* * *}$ & -.03 & -.05 & -.07 & -.03 & $.20 * * *$ & $.09 * *$ & $-.11 * *$ & $-.08 *$ & 1 & $-.08 *$ & $-.22 * * *$ & $-.08 *$ & $-.15^{* * *}$ & $-.13^{* * * *}$ \\
\hline 14. INDUSTRY_4 & $.09 *$ & .04 & -.01 & .07 & .07 & -.06 & -.04 & .07 & $.09 * *$ & $.10^{* *}$ & $-.08 *$ & -.05 & $-.08 *$ & 1 & $-.16^{* * *}$ & -.06 & $-.11 * *$ & $-.09 * *$ \\
\hline 15. INDUSTRY_5 & .05 & -.02 & -.04 & .04 & .05 & -.02 & $-.09 * *$ & -.05 & $.16^{* * *}$ & .07 & $-.24 * * *$ & $-.16 * * *$ & $-.22 * * *$ & $-.16^{* * *}$ & 1 & $-.17 * * *$ & $-.32 * * *$ & $-.27 * * *$ \\
\hline 16. INDUSTRY_6 & -.00 & .05 & $.11 * *$ & -.06 & -.04 & $.11 * *$ & -.03 & -.02 & $-.09 * *$ & -.07 & $-.09 * *$ & -.06 & $-.08^{*}$ & -.06 & $-.17 * * *$ & 1 & $-.12 * * *$ & $-.10^{* *}$ \\
\hline 17. INDUSTRY_7 & $-.09 * *$ & $-.08 *$ & -.02 & -.07 & .02 & -.05 & -.03 & .05 & $-.18 * * *$ & -.05 & $-.17 * * *$ & $-.11 * *$ & $-.15^{* * * *}$ & $-.11 * *$ & $-.32 * * *$ & $-.12 * * *$ & 1 & $-.19 * * *$ \\
\hline 18. INDUSTRY_8 & -.05 & -.03 & .07 & $-.08 *$ & -.07 & .02 & $.19^{* * *}$ & -.02 & $-.22 * * *$ & $-.14 * * *$ & $-.14 * * *$ & $-.09 * *$ & $-.13 * * *$ & $-.09 * *$ & $-.27 * * *$ & $-.10 * *$ & $-.19 * * *$ & 1 \\
\hline
\end{tabular}


Table 4. Regression results (logistic regression and ordered logistic regression)

\begin{tabular}{|c|c|c|c|c|}
\hline Model & 1 & 2 & 3 & 4 \\
\hline Dependent variable: & \multicolumn{2}{|c|}{ Auditor ENGAGEMENT } & \multicolumn{2}{|c|}{ Auditor ASSURANCE } \\
\hline Imaepenaent vartables. & & & & \\
\hline MAN_OWN & $\begin{array}{l}-0.0052 \\
(0.0033)\end{array}$ & $\begin{array}{l}-0.0080 * * \\
(0.0035)\end{array}$ & $\begin{array}{l}-0.0021 \\
(0.0024)\end{array}$ & $\begin{array}{l}-0.0026 \\
(0.0025)\end{array}$ \\
\hline GENERATION & & $\begin{array}{l}-1.2871 * * \\
(0.6450)\end{array}$ & & $\begin{array}{l}-0.1788 \\
(0.6149)\end{array}$ \\
\hline MAN_OWN*GENERATION & & $\begin{array}{l}0.0247 * * \\
(0.0104)\end{array}$ & & $\begin{array}{c}0.0039 \\
(0.0075)\end{array}$ \\
\hline LEVERAGE & $\begin{array}{c}0.2119 \\
(0.1411)\end{array}$ & $\begin{array}{c}0.2147 \\
(0.1510)\end{array}$ & $\begin{array}{c}0.2684 * * \\
(0.1051)\end{array}$ & $\begin{array}{l}0.2422 * * \\
(0.1119)\end{array}$ \\
\hline LEVERAGE*GENERATION & & $\begin{array}{l}-0.0077 \\
(0.1001)\end{array}$ & & $\begin{array}{c}0.0855 \\
(0.0708)\end{array}$ \\
\hline ROA & $\begin{array}{l}-0.0056 \\
(0.0481)\end{array}$ & $\begin{array}{l}-0.0012 \\
(0.0491)\end{array}$ & $\begin{array}{l}-0.0193 \\
(0.0574)\end{array}$ & $\begin{array}{l}-0.0121 \\
(0.0581)\end{array}$ \\
\hline QUICK & $\begin{array}{c}0.0033 \\
(0.0034)\end{array}$ & $\begin{array}{c}0.0036 \\
(0.0033)\end{array}$ & $\begin{array}{c}0.0034 \\
(0.0034)\end{array}$ & $\begin{array}{c}0.0034 \\
(0.0034)\end{array}$ \\
\hline DISTRESS & $\begin{array}{l}-0.1250 \\
(0.3542)\end{array}$ & $\begin{array}{l}-0.1034 \\
(0.3568)\end{array}$ & $\begin{array}{l}-0.3235 \\
(0.2765)\end{array}$ & $\begin{array}{l}-0.2999 \\
(0.2789)\end{array}$ \\
\hline SIZE & $\begin{array}{l}0.2730 \text { *** } \\
(0.0668)\end{array}$ & $\begin{array}{l}0.2717 * * * \\
(0.0677)\end{array}$ & $\begin{array}{l}0.2411 * * * \\
(0.0584)\end{array}$ & $\begin{array}{l}0.2389 \text { *** } \\
(0.0588)\end{array}$ \\
\hline LIMITED & $\begin{array}{l}-0.3878 \\
(0.2952)\end{array}$ & $\begin{array}{l}-0.4132 \\
(0.3012)\end{array}$ & $\begin{array}{l}-0.2084 \\
(0.2678)\end{array}$ & $\begin{array}{l}-0.2020 \\
(0.2685)\end{array}$ \\
\hline INDUSTRY_1 & $\begin{array}{l}-0.2893 \\
(0.3738)\end{array}$ & $\begin{array}{l}-0.3623 \\
(0.3793)\end{array}$ & $\begin{array}{l}-0.2065 \\
(0.3664)\end{array}$ & $\begin{array}{l}-0.2288 \\
(0.3698)\end{array}$ \\
\hline INDUSTRY_2 & $\begin{array}{l}-0.5893 \\
(0.4981)\end{array}$ & $\begin{array}{l}-0.6412 \\
(0.5013)\end{array}$ & $\begin{array}{l}-0.2156 \\
(0.5554)\end{array}$ & $\begin{array}{l}-0.2207 \\
(0.5555)\end{array}$ \\
\hline INDUSTRY_3 & $\begin{array}{c}0.5371 \\
(0.4809)\end{array}$ & $\begin{array}{c}0.3924 \\
(0.4908)\end{array}$ & $\begin{array}{c}0.3828 \\
(0.3745)\end{array}$ & $\begin{array}{c}0.3444 \\
(0.3809)\end{array}$ \\
\hline INDUSTRY_4 & $\begin{array}{c}0.7748 \\
(0.6136)\end{array}$ & $\begin{array}{c}0.7729 \\
(0.6268)\end{array}$ & $\begin{array}{c}0.0414 \\
(0.3566)\end{array}$ & $\begin{array}{l}-0.0024 \\
(0.3590)\end{array}$ \\
\hline INDUSTRY_5 & $\begin{array}{c}0.0061 \\
(0.3244)\end{array}$ & $\begin{array}{l}-0.0334 \\
(0.3263)\end{array}$ & $\begin{array}{l}-0.2435 \\
(0.3078)\end{array}$ & $\begin{array}{l}-0.2503 \\
(0.3102)\end{array}$ \\
\hline INDUSTRY_6 & $\begin{array}{c}0.2337 \\
(0.4681)\end{array}$ & $\begin{array}{c}0.2270 \\
(0.4670)\end{array}$ & $\begin{array}{c}0.6278 \\
(0.5181)\end{array}$ & $\begin{array}{c}0.6268 \\
(0.5154)\end{array}$ \\
\hline INDUSTRY_7 & $\begin{array}{l}-0.2566 \\
(0.3573)\end{array}$ & $\begin{array}{l}-0.2982 \\
(0.3610)\end{array}$ & $\begin{array}{l}-0.2379 \\
(0.3453)\end{array}$ & $\begin{array}{l}-0.2400 \\
(0.3463)\end{array}$ \\
\hline Intercept 1 & $\begin{array}{l}-2.3802 * * * \\
(0.9186)\end{array}$ & $\begin{array}{l}-2.1128^{* *} \\
(0.9297)\end{array}$ & $\begin{array}{l}2.3006 \text { *** } \\
(0.8015)\end{array}$ & $\begin{array}{l}2.2316^{* * * *} \\
(0.8034)\end{array}$ \\
\hline Intercept 2 & & & $\begin{array}{l}2.9919 * * * \\
(0.8133)\end{array}$ & $\begin{array}{l}2.9243 \text { *** } \\
(0.8153)\end{array}$ \\
\hline Intercept 3 & & & $\begin{array}{l}3.9392 * * * \\
(0.8306)\end{array}$ & $\begin{array}{l}3.8718 \text { **** } \\
(0.8324)\end{array}$ \\
\hline Log likelihood & -286.49 & -283.29 & -626.33 & -625.80 \\
\hline Chi-square & $36.02 * * *$ & $41.03 * * *$ & $35.83 * * *$ & $40.55 * * *$ \\
\hline Nagelkerke $\mathrm{R}^{2}$ & 0.120 & 0.137 & 0.089 & 0.091 \\
\hline McFadden $\mathrm{R}^{2}$ & 0.071 & 0.081 & 0.032 & 0.033 \\
\hline Cox-Snell R² & 0.087 & 0.099 & 0.083 & 0.085 \\
\hline
\end{tabular}

$\mathrm{N}=482 ; *, * *, * * *$ indicate significance at the $10 \%, 5 \%$ and $1 \%$ levels respectively (two-tailed); For variable definitions, please refer to table 1 .

Notes: This table presents our logistic (logit) and ordered logistic (ologit) regression results. Both the Beta coefficients and the robust standard errors (between brackets) are reported per variable for each model. In this table, also the Log likelihood and the Chi-square statistics are reported for each model, as well as three goodness of fit measures (Nagelkerke $\mathrm{R}^{2}$, McFadden $\mathrm{R}^{2}$ and Cox-Snell $\mathrm{R}^{2}$ ). 
Table 5. Multinomial logistic regression results

\begin{tabular}{|c|c|c|c|c|c|c|}
\hline \multirow{3}{*}{$\begin{array}{l}\text { Model } \\
\text { Dependent variable: } \\
\text { Auditor ASSURANCE }\end{array}$} & \multicolumn{3}{|c|}{1} & \multicolumn{3}{|c|}{2} \\
\hline & & & & & & \\
\hline & COMPILATION & REVIEW & AUDIT & COMPILATION & REVIEW & AUDIT \\
\hline \multicolumn{7}{|l|}{ Independent variables: } \\
\hline MAN_OWN & $\begin{array}{l}-0.0085 * \\
(0.0047)\end{array}$ & $\begin{array}{l}-0.0051 \\
(0.0041)\end{array}$ & $\begin{array}{l}-0.0034 \\
(0.0038)\end{array}$ & $\begin{array}{l}-0.0131 * * * \\
(0.0050)\end{array}$ & $\begin{array}{l}-0.0092 * * \\
(0.0044)\end{array}$ & $\begin{array}{l}-0.0042 \\
(0.0041)\end{array}$ \\
\hline GENERATION & & & & $\begin{array}{l}-2.7684 * * * \\
(1.0523)\end{array}$ & $\begin{array}{l}-1.7724^{*} \\
(0.9203)\end{array}$ & $\begin{array}{l}-0.4499 \\
(0.7269)\end{array}$ \\
\hline MAN_OWN*GENERATION & & & & $\begin{array}{l}0.0433 * * * \\
(0.0145)\end{array}$ & $\begin{array}{l}0.0346^{* * * *} \\
(0.0135)\end{array}$ & $\begin{array}{c}0.0097 \\
(0.0118)\end{array}$ \\
\hline LEVERAGE & $\begin{array}{l}-0.5912 \\
(0.3677)\end{array}$ & $\begin{array}{c}0.2844 \\
(0.1811)\end{array}$ & $\begin{array}{l}0.3345^{* * *} \\
(0.1638)\end{array}$ & $\begin{array}{l}-0.5795 \\
(0.3795)\end{array}$ & $\begin{array}{c}0.3271^{*} \\
(0.1872)\end{array}$ & $\begin{array}{c}0.2885 \\
(0.1776)\end{array}$ \\
\hline LEVERAGE*GENERATION & & & & $\begin{array}{c}0.0501 \\
(0.1843)\end{array}$ & $\begin{array}{l}-0.1486 \\
(0.1375)\end{array}$ & $\begin{array}{c}0.0712 \\
(0.1148)\end{array}$ \\
\hline ROA & $\begin{array}{l}-0.0605 \\
(0.0823)\end{array}$ & $\begin{array}{c}0.0555 \\
(0.0526)\end{array}$ & $\begin{array}{l}-0.0350 \\
(0.0761)\end{array}$ & $\begin{array}{l}-0.0509 \\
(0.0799)\end{array}$ & $\begin{array}{c}0.0533 \\
(0.0535)\end{array}$ & $\begin{array}{l}-0.0258 \\
(0.0758)\end{array}$ \\
\hline QUICK & $\begin{array}{c}0.0017 \\
(0.0048)\end{array}$ & $\begin{array}{c}0.0017 \\
(0.0050)\end{array}$ & $\begin{array}{c}0.0044 \\
(0.0039)\end{array}$ & $\begin{array}{c}0.0021 \\
(0.0046)\end{array}$ & $\begin{array}{c}0.0023 \\
(0.0050)\end{array}$ & $\begin{array}{c}0.0045 \\
(0.0039)\end{array}$ \\
\hline DISTRESS & $\begin{array}{c}0.8256 \\
(0.6054)\end{array}$ & $\begin{array}{c}0.1639 \\
(0.4480)\end{array}$ & $\begin{array}{l}-0.6002 \\
(0.4392)\end{array}$ & $\begin{array}{c}0.8674 \\
(0.6082)\end{array}$ & $\begin{array}{c}0.1873 \\
(0.4508)\end{array}$ & $\begin{array}{l}-0.5548 \\
(0.4422)\end{array}$ \\
\hline SIZE & $\begin{array}{c}0.1370 \\
(0.0923)\end{array}$ & $\begin{array}{l}0.3702 * * * \\
(0.0882)\end{array}$ & $\begin{array}{l}0.2870 * * * \\
(0.0836)\end{array}$ & $\begin{array}{c}0.1411 \\
(0.0951)\end{array}$ & $\begin{array}{l}0.3692 * * * \\
(0.0888)\end{array}$ & $\begin{array}{l}0.2818^{* * * *} \\
(0.0844)\end{array}$ \\
\hline LIMITED & $\begin{array}{l}-0.4807 \\
(0.4166)\end{array}$ & $\begin{array}{l}-0.3678 \\
(0.4384)\end{array}$ & $\begin{array}{l}-0.3164 \\
(0.3682)\end{array}$ & $\begin{array}{l}-0.5158 \\
(0.4186)\end{array}$ & $\begin{array}{l}-0.4020 \\
(0.4371)\end{array}$ & $\begin{array}{l}-0.3241 \\
(0.3738)\end{array}$ \\
\hline INDUSTRY_1 & $\begin{array}{l}-0.3972 \\
(0.5886)\end{array}$ & $\begin{array}{l}-0.2391 \\
(0.5418)\end{array}$ & $\begin{array}{l}-0.2998 \\
(0.4518)\end{array}$ & $\begin{array}{l}-0.5260 \\
(0.6069)\end{array}$ & $\begin{array}{l}-0.3720 \\
(0.5391)\end{array}$ & $\begin{array}{l}-0.3135 \\
(0.4534)\end{array}$ \\
\hline INDUSTRY_2 & $\begin{array}{l}-0.9979 \\
(0.8704)\end{array}$ & $\begin{array}{l}-1.0019 \\
(0.7323)\end{array}$ & $\begin{array}{l}-0.2879 \\
(0.5837)\end{array}$ & $\begin{array}{l}-1.1114 \\
(0.8678)\end{array}$ & $\begin{array}{l}-1.0912 \\
(0.7383)\end{array}$ & $\begin{array}{l}-0.2823 \\
(0.5846)\end{array}$ \\
\hline INDUSTRY_3 & $\begin{array}{l}-0.0697 \\
(0.7797)\end{array}$ & $\begin{array}{c}0.7348 \\
(0.5819)\end{array}$ & $\begin{array}{c}0.5563 \\
(0.5467)\end{array}$ & $\begin{array}{l}-0.2968 \\
(0.7967)\end{array}$ & $\begin{array}{c}0.4728 \\
(0.6067)\end{array}$ & $\begin{array}{c}0.5181 \\
(0.5516)\end{array}$ \\
\hline INDUSTRY_4 & $\begin{array}{c}1.1619 \\
(0.7690)\end{array}$ & $\begin{array}{c}1.0722 \\
(0.7152)\end{array}$ & $\begin{array}{c}0.1681 \\
(0.7041)\end{array}$ & $\begin{array}{c}1.2256 \\
(0.7831)\end{array}$ & $\begin{array}{c}1.1502 \\
(0.7320)\end{array}$ & $\begin{array}{c}0.0972 \\
(0.7347)\end{array}$ \\
\hline INDUSTRY_5 & $\begin{array}{c}0.5077 \\
(0.4581)\end{array}$ & $\begin{array}{c}0.0416 \\
(0.4394)\end{array}$ & $\begin{array}{l}-0.3456 \\
(0.4077)\end{array}$ & $\begin{array}{c}0.4545 \\
(0.4565)\end{array}$ & $\begin{array}{l}-0.0196 \\
(0.4438)\end{array}$ & $\begin{array}{l}-0.3415 \\
(0.4083)\end{array}$ \\
\hline INDUSTRY_6 & $\begin{array}{l}-0.1892 \\
(0.7569)\end{array}$ & $\begin{array}{l}-0.7841 \\
(0.9281)\end{array}$ & $\begin{array}{c}0.6442 \\
(0.5209)\end{array}$ & $\begin{array}{l}-0.2067 \\
(0.7649)\end{array}$ & $\begin{array}{l}-0.7888 \\
(0.9330)\end{array}$ & $\begin{array}{c}0.6349 \\
(0.5172)\end{array}$ \\
\hline INDUSTRY_7 & $\begin{array}{l}-0.3858 \\
(0.5144)\end{array}$ & $\begin{array}{c}0.0908 \\
(0.4984)\end{array}$ & $\begin{array}{l}-0.4486 \\
(0.4384)\end{array}$ & $\begin{array}{l}-0.4761 \\
(0.5199)\end{array}$ & $\begin{array}{c}0.0056 \\
(0.5106)\end{array}$ & $\begin{array}{l}-0.4369 \\
(0.4371)\end{array}$ \\
\hline
\end{tabular}




\begin{tabular}{|c|c|c|c|c|c|c|}
\hline Intercept & $\begin{array}{l}-1.3918 \\
(1.2879)\end{array}$ & $\begin{array}{l}-5.1226 * * * \\
(1.2074)\end{array}$ & $\begin{array}{l}-3.4606 * * * \\
(1.1472)\end{array}$ & $\begin{array}{l}-1.0396 \\
(1.3286)\end{array}$ & $\begin{array}{l}-4.7708 * * * \\
(1.2226)\end{array}$ & $\begin{array}{l}-3.3097 * * * * \\
(1.1524)\end{array}$ \\
\hline Log pseudolikelihood & -603.74 & & & -595.97 & & \\
\hline Chi-square & $80.25^{* * * *}$ & & & $100.69^{* * *}$ & & \\
\hline Nagelkerke $\mathrm{R}^{2}$ & 0.177 & & & 0.206 & & \\
\hline McFadden $\mathrm{R}^{2}$ & 0.067 & & & 0.079 & & \\
\hline Cox-Snell R² & 0.165 & & & 0.192 & & \\
\hline
\end{tabular}

$\mathrm{N}=482 ; *, * *, * * *$ indicate significance at the $10 \%, 5 \%$ and $1 \%$ levels respectively (two-tailed); For variable definitions, please refer to table 1.

Notes: This table presents our multinomial logistic regression results. Both the Beta coefficients and the robust standard errors (between brackets) are reported per variable. In this table, also the Log pseudolikelihood and the Chi-square statistics are reported for both models, as well as three goodness of fit measures (Nagelkerke $\mathrm{R}^{2}$, McFadden $\mathrm{R}^{2}$ and Cox-Snell $\mathrm{R}^{2}$ ). 